\title{
An Essential Role of Fyn in the Modulation of Metabotropic Glutamate Receptor 1 in Neurons
}

\author{
Dao-Zhong Jin, ${ }^{1}$ Li-Min Mao, ${ }^{1}$ and John Q. Wang ${ }^{1,2,3}$
}

DOI:http://dx.doi.org/10.1523/ENEURO.0096-17.2017

${ }^{1}$ Department of Basic Medical Science, School of Medicine, University of Missouri-Kansas City, Kansas City, Missouri 64108, ${ }^{2}$ Department of Anesthesiology, School of Medicine, University of Missouri-Kansas City, Kansas City, Missouri 64108, and ${ }^{3}$ Beijing Institute of Brain Disorders, Capital Medical University, Beijing 100069, People's Republic of China

\begin{abstract}
Fyn is a member of the Src family of nonreceptor tyrosine kinases and is broadly expressed in the CNS. As a synapse-enriched kinase, Fyn interacts with and phosphorylates local substrates to regulate synaptic transmission and plasticity, although our knowledge of specific targets of Fyn at synaptic sites remains incomplete and the accurate role of Fyn in regulating synaptic proteins is poorly understood. In this study, we initiated an effort to explore the interaction of Fyn with a metabotropic glutamate receptor (mGluR). We found that recombinant Fyn directly binds to mGluR1a at a consensus binding motif located in the intracellular C-terminus (CT) of mGluR1a in vitro. Similarly, endogenous Fyn interacts with mGluR1a in adult rat cerebellar neurons in vivo. Active Fyn phosphorylates mGluR1a at a conserved tyrosine residue in the CT region. In cerebellar neurons and transfected HEK293T cells, the Fyn-mediated tyrosine phosphorylation of mGluR1a is constitutively active and acts to facilitate the surface expression of mGluR1a and to potentiate the mGluR1a postreceptor signaling. These results support mGluR1a to be a novel substrate of Fyn. Fyn, by binding to and phosphorylating mGluR1a, potentiates surface expression and signaling of the receptors.
\end{abstract}

Key words: cerebellum; mGluR; phosphorylation; Src

\section{Significance Statement}

This work identified a novel signaling mechanism in cerebellar neurons. In these neurons, a nonreceptor tyrosine kinase, Fyn, binds to a glutamate receptor [i.e., metabotropic glutamate receptor 1 (mGluR1)] at synaptic sites. This binding enables the kinase to phosphorylate the receptor at a specific tyrosine site, thereby regulating surface expression/trafficking and mGluR1 signaling. These findings unravel a new mechanism underlying the regulation of glutamate receptors by tyrosine kinases in cerebellar neurons and advance the current knowledge on molecular neurobiology of glutamate receptors.

\section{Introduction}

L-Glutamate, a key transmitter in the brain, interacts with ionotropic and metabotropic glutamate receptors (mGluR) to achieve its action (Niswender and Conn, 2010;

Received March 21, 2017; accepted August 15, 2017; First published August 24, 2017.

The authors declare no competing financial interests.

Author contributions: D.-Z.J., L.-M.M., and J.Q.W. designed research; D.Z.J. performed experiments; D.-Z.J. and J.Q.W. analyzed data; D.-Z.J., L.M.M., and J.Q.W. wrote the paper.

This work was supported by National Institutes of Health Grants DA-10355 (J.Q.W.) and MH-61469 (J.Q.W.).

Acknowledgments: We thank Drs. Minglei Guo and Bing Xue for technical assistance and Dr. Mingui Fu for providing HEK293T cells, which were
Traynelis et al., 2010). Among eight mGluR subtypes (mGluR1-8), mGluR1 has been an attractive target in recent studies. As a G-protein-coupled receptor (GPCR), mGluR1 activates $\mathrm{G}_{\alpha \mathrm{q}}$-coupled phospholipase $\mathrm{C} \beta 1$ (PLC $\left.\beta 1\right)$. This

originally purchased from the American Type Culture Collection.

Correspondence should be addressed to Dr. John Q. Wang, Department of Basic Medical Science, University of Missouri-Kansas City, School of Medicine, 2411 Holmes Street, Kansas City, MO 64108. E-mail: wangjq@umkc.edu.

DOI:http://dx.doi.org/10.1523/ENEURO.0096-17.2017 Copyright (C) 2017 Jin et al.

This is an open-access article distributed under the terms of the Creative Commons Attribution 4.0 International license, which permits unrestricted use, distribution and reproduction in any medium provided that the original work is properly attributed. 
leads to an increase in phosphoinositide hydrolysis, yielding diacylglycerol and inositol triphosphate $\left(\mathrm{IP}_{3}\right)$ to trigger protein kinase $\mathrm{C}(\mathrm{PKC})$ and $\mathrm{Ca}^{2+}$ signaling pathways, respectively (Niswender and Conn, 2010). Noticeably, mGluR1 is enriched in the cerebellum (Martin et al., 1992) and is distributed mostly at perisynaptic and postsynaptic sites (Lujan et al., 1996; Kuwajima et al., 2004). Thus, mGluR1 plays a pivotal role in the regulation of synaptic transmission (Traynelis et al., 2010; Nicoletti et al., 2011). mGluR1 is regulated by a phosphorylation-dependent mechanism. Like many other membrane-bound GPCRs, mGluR1 has four intracellular domains, including three intracellular loops (ILs; IL1, IL2, and IL3) and a C-terminal tail. It is the C terminus (CT) that is large in size (359 aa in a long-form splice-variant mGluR1a) and is sufficient to provide a space for proteinprotein interactions. In fact, a number of submembranous proteins have been identified to interact with mGluR1 CT (Enz, 2007; 2012; Fagni, 2012). One group of noticeable mGluR1 interacting partners is protein kinases. These kinases are thought to phosphorylate specific residues in mGluR1a CT and thereby modulate function of the modified receptors (Kim et al., 2008; Mao et al., 2011). However, responsible kinases and detailed mechanisms underlying their regulatory roles are poorly understood.

Proteins can be phosphorylated at tyrosine sites by receptor or nonreceptor tyrosine kinases. Src family kinases (SFKs), a subfamily of nonreceptor tyrosine kinases (Neet and Hunter, 1996), have been studied mostly for their roles in phosphorylating and regulating proteins. Five SFK members of a total of nine are expressed in the brain (Mao and Wang, 2016). Among these five SFK members, Fyn (isoform 1, also known as FynB), a $59 \mathrm{kDa}$ protein, is of particular interest (Cooke and Perlmutter, 1989; Saito et al., 2010). This kinase is enriched at synaptic structures. Thus, Fyn is thought to function at synaptic sites and act as a key regulator in synaptic transmission and plasticity (Neet and Hunter, 1996). Indeed, Fyn tyrosinephosphorylates ionotropic glutamate receptors and other synaptic proteins, thereby modulating the expression and function of these receptors/proteins and synaptic signaling (Ohnishi et al., 2011; Schenone et al., 2011). However, at present, whether and how Fyn regulates mGluRs remain elusive.

This study therefore explored possible Fyn-mGluR interactions. We found that mGluR1a is a novel substrate of Fyn. Recombinant Fyn directly binds to mGluR1a at its CT region in vitro. Endogenous Fyn forms complexes with mGluR1a in rat cerebellar neurons in vivo. Active Fyn phosphorylates the mGluR1a CT at a specific tyrosine site. This phosphorylation is functionally relevant as it significantly modulates surface expression and mGluR1a signaling in cerebellar neurons and HEK293T cells. Together, we have discovered a previously unrecognized Fyn-mGluR1a coupling that is involved in the regulation of mGluR1a.

\section{Materials and Methods}

\section{Animals}

Adult male Wistar rats (weight, 200-300 g) were purchased from Charles River. Animals were individually housed at a temperature of $23^{\circ} \mathrm{C}$ and a humidity of $50 \pm$ $10 \%$ with food and water available ad libitum. The animal room was on a $12 \mathrm{~h}$ light/dark cycle with lights on at 7:00 A.M. All animal use procedures were in strict accordance with the National Institutes of Health Guide for the Care and Use of Laboratory Animals and were approved by the Institutional Animal Care and Use Committee.

\section{Glutathione S-transferase fusion protein synthesis}

Glutathione S-transferase (GST) fusion proteins were synthesized. The cDNA fragments encode mGluR1aCT1(K841-T1000), mGluR1a-CT2(P1001-L1199), mGluR1a-CT1a(K841-N885), mGluR1a-CT1b(A886K931), mGluR1a-CT1c(N925-T1000), mGluR1a-IL1(R618E629), mGluR1a-IL2(K678-Q706), mGluR1a-IL3(K773K785), GluA1-CT (E809-L889), and GluA2-CT (E834-I883). These cDNA fragments were generated by PCR amplification from full-length (FL) cDNA clones (rat mGluR1; UniProtKB accession \#P23385) and subcloned into BamHI-EcoRI sites of the pGEX4T-3 plasmid (GE Healthcare). To confirm appropriate splice fusion, constructs were sequenced. GST fusion proteins were expressed in Escherichia coli BL21 cells and purified as described by the manufacturer.

\section{Cell cultures and transfection}

HEK293T cells were cultured in Eagle's Minimum Essential Medium from American Type Culture Collection at $37^{\circ} \mathrm{C}$ with $5 \% \quad \mathrm{CO}_{2}$. The medium contains $10 \%$ fetal bovine serum and $1 \%$ penicillin-streptomycin (SigmaAldrich). Transfections were conducted on an $\sim 70-80 \%$ confluent monolayer using Lipofectamine 2000 (Thermo Fisher Scientific) according to the manufacturer instructions. Experiments were performed $18 \mathrm{~h}$ after the transfection. Mammalian expression vectors for expressing proteins with a FLAG tag include FL rat mGluR1a and Fyn wild type (WT) in pcDNA3.1 + C(K)DYK vectors bearing the CMV promoter (GenScript) and the pcDNA3.1 + $\mathrm{C}(\mathrm{K}) \mathrm{DYK}$ empty vector control. Site-directed mutations were introduced into pcDNA3.1(+) constructs containing mGluR1a or Fyn by a QuikChange site-directed mutagenesis kit (Stratagene).

\section{Affinity purification (pull-down) assay}

Pull-down assays were conducted with solubilized rat cerebellar lysates $(50-100 \mu \mathrm{g})$ according to the procedures described previously (Liu et al., 2009; Guo et al., 2010). At least three experiments were performed for each analysis.

\section{In vitro binding assay}

Recombinant His-tagged active Fyn (FynB) with an FL of 537 aa (10 ng; Millipore), His-tagged paxillin (10 ng; RayBiotech), FLAG-tagged focal adhesion kinase (Fak; 10 ng) or FLAG-tagged Fyn mutant (Y531F or K299M) was equilibrated to binding buffer containing $200 \mathrm{mM} \mathrm{NaCl}$, $0.2 \%$ Triton $\mathrm{X}-100,0.1 \mathrm{mg} / \mathrm{ml}$ bovine serum albumin (BSA), and $50 \mathrm{~mm}$ Tris, $\mathrm{pH}$ 7.5. Binding reactions were initiated by adding purified GST fusion proteins and continued for $2-3 \mathrm{~h}$ at $4^{\circ} \mathrm{C}$. We then used glutathione Sepharose 4B beads $(10 \%, 100 \mu \mathrm{l})$ to precipitate GST fusion 
A

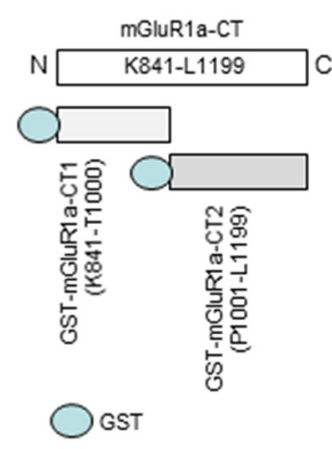

B
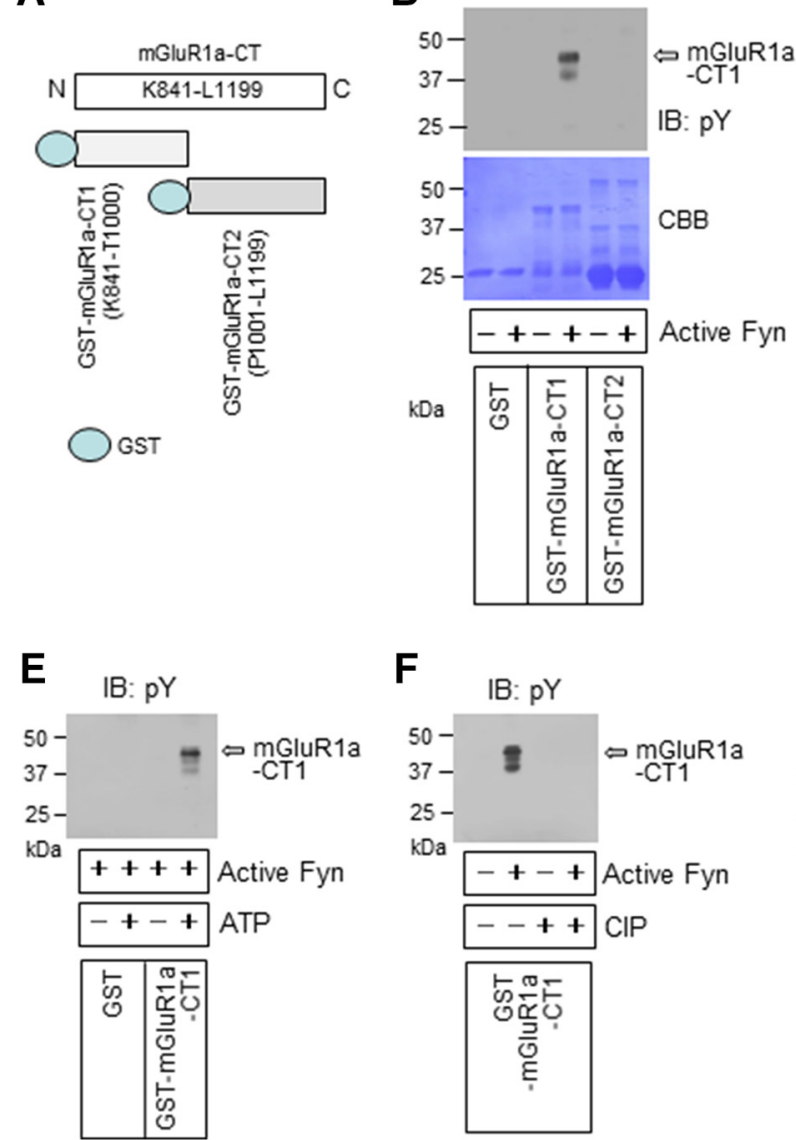

F

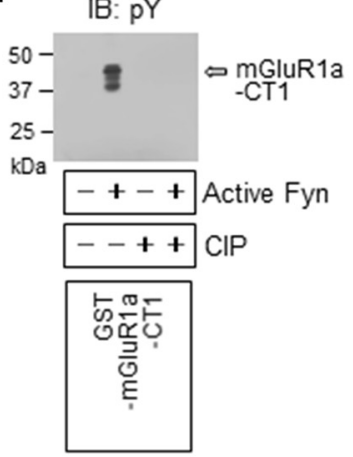

C

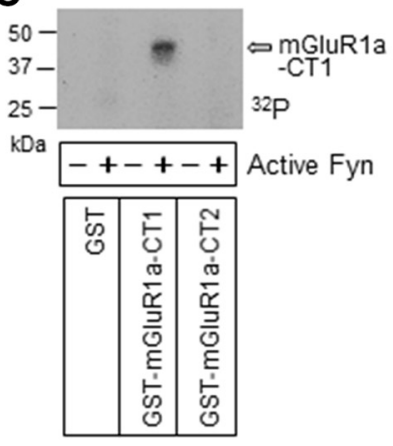

D

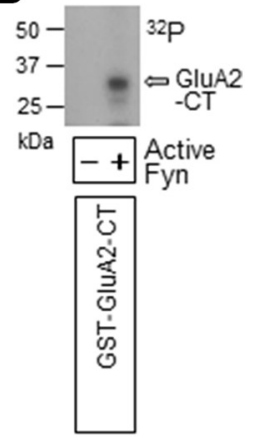

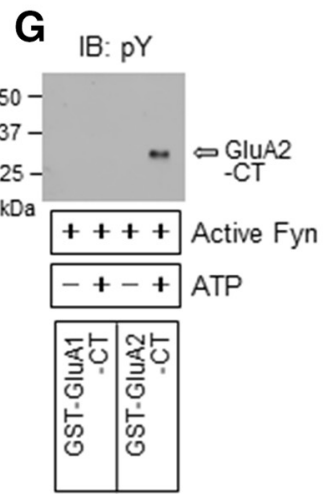

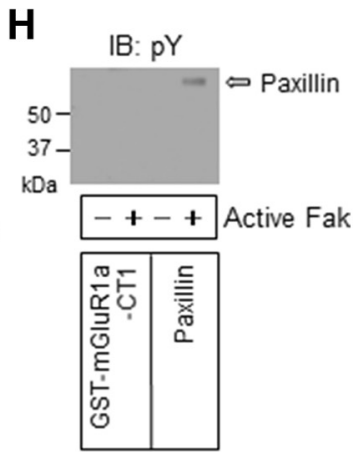

Figure 1. Phosphorylation of mGluR1a by Fyn. $\boldsymbol{A}$, GST-mGluR1a-CT1 and GST-mGluR1a-CT2 proteins synthesized from rat mGluR1a-CT FL. B, A representative immunoblot illustrating phosphorylation of GST-mGluR1a-CT1 by Fyn. Tyrosine phosphorylation levels were detected by an antibody against pY. A membrane staining with Coomassie Brilliant Blue (CBB) is present below to show protein loading. Note that GST-mGluR1a-CT1 was phosphorylated, while GST-mGluR1a-CT2 and GST alone were not. $\boldsymbol{C}$, A representative autoradiograph illustrating phosphorylation of GST-mGluR1a-CT1 by Fyn. $\boldsymbol{D}$, An autoradiograph illustrating phosphorylation of GST-GluA2-CT by Fyn. $\boldsymbol{E}$, Phosphorylation of GST-mGluR1a-CT1 in the presence but not the absence of ATP. $\boldsymbol{F}$, Dephosphorylation of Fyn-mediated phosphorylation of GST-mGluR1a-CT1 by CIP. G, Phosphorylation of GST-GluA2-CT by Fyn. In contrast to GST-GluA2-CT, phosphorylation of GST-GluA1-CT was not observed. $\boldsymbol{H}$, A representative immunoblot showing phosphorylation responses of GST-mGluR1a-CT1 to Fak. Note that Fak did not phosphorylate mGluR1a-CT1, while it phosphorylated paxillin, a known substrate of Fak. All phosphorylation reactions were conducted with active Fyn or Fak at $30^{\circ} \mathrm{C}$ for 30 min $(\boldsymbol{B}-\boldsymbol{H})$ followed by dephosphorylation reactions $(\boldsymbol{F})$. The reactions were subjected to gel electrophoresis followed by autoradiography $(\boldsymbol{C}, \boldsymbol{D})$ or immunoblot (IB) with an anti-pY antibody $(\boldsymbol{B}, \boldsymbol{E}-\boldsymbol{H})$. Open arrows indicate phosphorylated GST-mGluR1a-CT1 (B, C, $\boldsymbol{E}, \boldsymbol{F})$, GST-GluA2-CT $(\boldsymbol{D}, \boldsymbol{G})$, or paxillin $(\boldsymbol{H})$. $\mathrm{N}, \mathrm{NH}_{2}$-terminus; $\mathrm{C}, \mathrm{COOH}$-terminus.

proteins. After the precipitate was washed three times, bound proteins were eluted with $4 \times$ lithium dodecyl sulfate (LDS) loading buffer, resolved by SDS-PAGE, and immunoblotted with the antibodies indicated.

\section{Phosphorylation assays in vitro}

GST fusion proteins or His-tagged paxillin (0.1-0.5 $\mu \mathrm{M})$ were incubated with recombinant active Fyn (SigmaAldrich) or Fak (Creative Biomart) for $30 \mathrm{~min}\left(30^{\circ} \mathrm{C}\right)$ in a reaction buffer $(25 \mu \mathrm{l})$ containing $10 \mathrm{~mm}$ HEPES, $\mathrm{pH} 7.4$, $10 \mathrm{mM} \mathrm{MgCl}, 1 \mathrm{mM} \mathrm{Na} \mathrm{VO}_{4}, 1 \mathrm{~mm}$ dithiothreitol, 0.1 $\mathrm{mg} / \mathrm{ml} \mathrm{BSA}$, and $50 \mu \mathrm{M}$ ATP. An amount of $2.5 \mu \mathrm{Ci} / \mathrm{tube}$ $\left[\gamma^{32}\right.$ P]ATP ( $\sim 3000 \mathrm{Ci} / \mathrm{mmol}$; PerkinElmer) was added for autoradiography. Phosphorylation reactions were stopped by adding and boiling the LDS sample buffer ( $3 \mathrm{~min}$ ). Phosphorylated proteins were resolved by SDS-PAGE and visu- alized by autoradiography or immunoblotting. The amount of radioactivity that was incorporated into the substrate bands was assessed by liquid scintillation counting of the radioactive substrate bands excised from the gels. At least three experiments were performed for each analysis. Phosphorylation stoichiometry was determined by the amount of radioactive phosphate incorporated into substrate (mol phosphate/mol substrate).

\section{Dephosphorylation reactions}

GST fusion proteins that were phosphorylated by the above procedure were precipitated, and the supernatant containing Fyn was removed. Precipitates were washed twice and were suspended in a solution containing $50 \mathrm{~mm}$ Tris- $\mathrm{HCl}, \mathrm{pH} 8.5,1 \mathrm{mM} \mathrm{MgCl}_{2}, 0.1 \mathrm{~mm} \mathrm{ZnCl}_{2}$, and calf intestine alkaline phosphatase (CIP; 100 units/ml; Roche). 
A

mGluR1a-CT1(K841-T1000)

KPERNVRSA FTTSDVVRMHVG DGKLPCRSNT FLNI FRRKKPGAGNANSNGKSVSWSE PGGRQA KGQHVWQRL SVHVKT NETACNQTAVIKPLTKSY YQGSGKSLTF SDASTKTLYNVEEEDNTPSAH

FSPPSSPSMVVHRRG PPVATT PPLPPHLTAEET

B

\begin{tabular}{|l|}
\multicolumn{1}{c|}{ Tyrosine site mutation } \\
\begin{tabular}{|l} 
GST-mGluR1a-CT1(K841-T1000)-WT \\
Mutation 1: CT1-Y937F \\
Mutation 2: CT1-Y955F \\
Mutation 3: CT1-Y937/955F \\
\hline
\end{tabular}
\end{tabular}

D

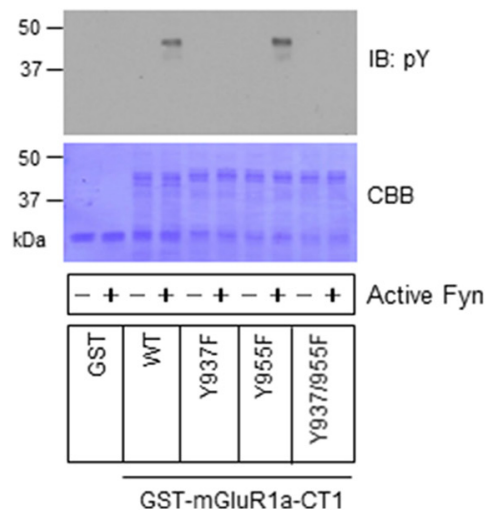

C

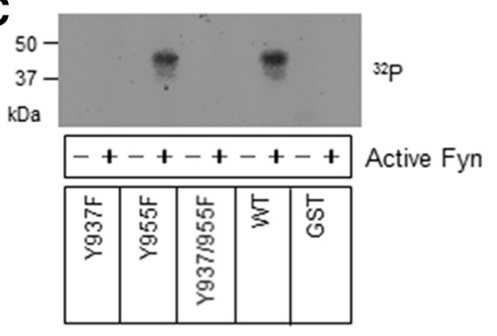

GST-mGluR1a-CT1

E

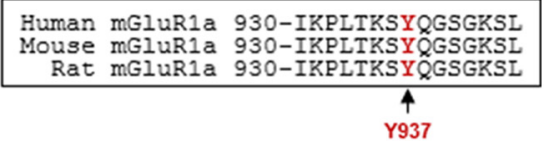

Figure 2. Phosphorylation of a tyrosine residue in mGluR1a-CT1 by Fyn. $\boldsymbol{A}$, Amino acid sequence of mGluR1a-CT1(K841-T1000). Two tyrosine residues, Y937 and Y955 (in red), are contained in this fragment. B, Site-directed mutation proteins derived from mGluR1a-CT1. Mutants include mutations of Y937 to phenylalanine (Y937F), Y955 to phenylalanine (Y955F), and both tyrosine sites (Y937 and Y955) to phenylalanine (Y937/955F). C, A representative autoradiograph showing phosphorylation of GST-mGluR1a-CT1 mutants and WT induced by active Fyn. Note that the Y955F mutant and WT showed similar phosphorylation by Fyn, while the Y937F and Y937/955F mutants showed no phosphorylation. $\boldsymbol{D}$, A representative immunoblot showing phosphorylation responses of the three mutants to active Fyn. Again, only the Y955F mutant and WT exhibited phosphorylation signals. A membrane staining with Coomassie Brilliant Blue (CBB) is present below to show protein loading. $\boldsymbol{E}$, The conserved Y937 residue (in red) in human, rat, and mouse mGluR1a. Phosphorylation of mGluR1a-CT1 (mutants or WT) was detected by ${ }^{32} \mathrm{P}$ incorporation autoradiography (C) or immunoblot (IB) with an antibody against pY (D).

The suspension was incubated for $1 \mathrm{~h}$ at $37^{\circ} \mathrm{C}$. Dephosphorylation reactions were stopped by adding an LDS sample buffer. Samples were then subjected to standard gel electrophoresis and immunoblotting.

\section{Coimmunoprecipitation}

The rat cerebellum was removed after anesthesia and decapitation and was homogenized in cold isotonic homogenization buffer containing $0.32 \mathrm{M}$ sucrose, $10 \mathrm{~mm}$ HEPES, pH 7.4, 2 mm EDTA, and a protease/phosphatase inhibitor cocktail (Thermo Fisher Scientific). Lysates were then processed at $4^{\circ} \mathrm{C}$. After centrifugation $(800 \times \mathrm{g}, 10$ $\mathrm{min})$, the supernatant was centrifuged again $(10,000 \times g$, $15 \mathrm{~min}$ ) to get P2 synaptosomal pellets. P2 pellets were solubilized in the buffer containing Triton $\mathrm{X}-100(0.5 \%$, $\mathrm{v} / \mathrm{v}), 1 \%$ sodium deoxycholate, and a protease/phosphatase inhibitor cocktail for $1 \mathrm{~h}$. After centrifugation, the solubilized supernatant was used for coimmunoprecipitation. HEK293T cells were lysed and solubilized in RIPA buffer (Sigma-Aldrich). Solubilized supernatant proteins after centrifugation were used for coimmunoprecipitation.
Solubilized samples were incubated with a rabbit or mouse antibody. The complex was precipitated with $50 \%$ protein $A$ and $G$ agarose/Sepharose bead slurry (GE Healthcare). Proteins were separated on Novex 4-12\% gels and probed with immunoblotting with a mouse or rabbit antibody if a rabbit or mouse antibody was used in immunoprecipitation, respectively.

\section{Cerebellar slice preparation}

After rats were anesthetized and decapitated, rat brains were removed. The cerebellum was cut into coronal slices (300 $\mu \mathrm{m})$ using a VT1200S vibratome (Leica). Slices were preincubated in artificial CSF (ACSF) containing the following (in mM): 10 glucose, $124 \mathrm{NaCl}, 3 \mathrm{KCl}, 1.25 \mathrm{KH}_{2} \mathrm{PO}_{4}$, $26 \mathrm{NaHCO}_{3}, 2 \mathrm{MgSO}_{4}$, and $2 \mathrm{CaCl}_{2}$, bubbled with $95 \%$ $\mathrm{O}_{2} / 5 \% \mathrm{CO}_{2}, \mathrm{pH} 7.4$, in an incubation tube at $30^{\circ} \mathrm{C}$ under constant oxygenation with $95 \% \mathrm{O}_{2} / 5 \% \mathrm{CO}_{2}$ for $60 \mathrm{~min}$. Additional preincubation after the solution was replaced with fresh ACSF was made for 10-20 min. Drugs were added and incubated at $30^{\circ} \mathrm{C}$. Slices were collected after drug treatment for neurochemical assays. 

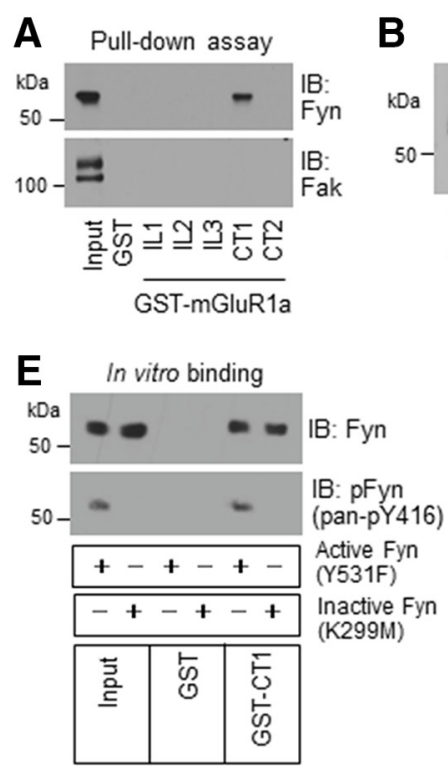

G

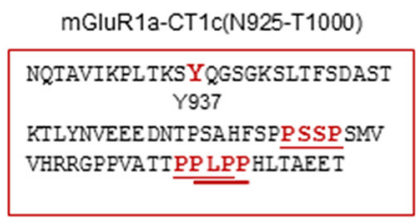

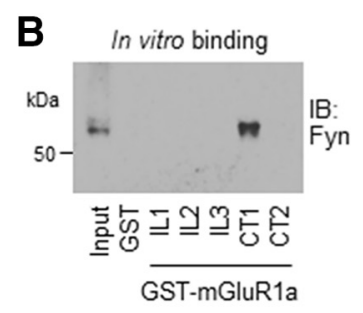
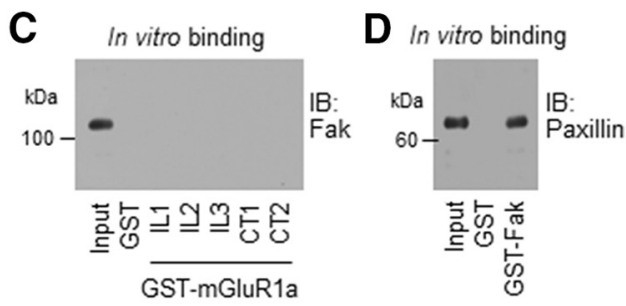

$\mathbf{F}$
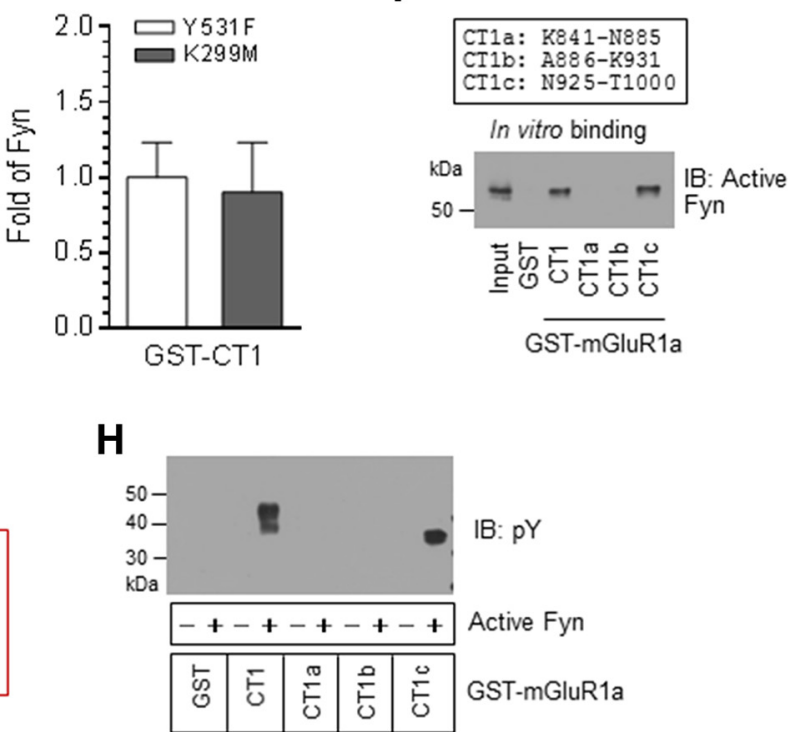

Figure 3. Interactions between Fyn and mGluR1a. A, Pull-down assays with immobilized GST fusion proteins containing distinct intracellular domains of mGluR1a. GST fusion proteins were incubated with adult rat cerebellar lysates. Note that CT1 but not other intracellular domains precipitated endogenous Fyn. No GST fusion proteins precipitated Fak. $\boldsymbol{B}, \boldsymbol{C}$, In vitro binding assays with immobilized GST fusion proteins and purified active Fyn $(\boldsymbol{B})$ and Fak $(\boldsymbol{C})$. Note that CT1 precipitated Fyn $(\boldsymbol{B})$ but not Fak $(\boldsymbol{C})$. $\boldsymbol{D}$, In vitro binding assays showing that GST-Fak precipitated paxillin. $\boldsymbol{E}$, Comparison between active and inactive Fyn in binding to mGluR1aCT1. A constitutively active Fyn mutant (Y531F) and a kinase-dead, inactive Fyn mutant (K299M) were used. Representative immunoblots are shown to the left of the quantified data. $\boldsymbol{F}$, In vitro binding assays with truncated mGluR1a-CT1 fragments (CT1a-c). Note that CT1c but not CT1a and CT1b precipitated Fyn. G, Fyn SH3 binding motifs (PXXP) in the CT1c region. Three PXXP motifs (underlined, in red) are revealed. $\boldsymbol{H}$, Tyrosine phosphorylation of CT1c by Fyn. Endogenous and recombinant Fyn proteins bound to GST fusion proteins were visualized by immunoblot (IB). Tyrosine phosphorylation of CT1c was detected by an anti-pY antibody. Data are presented as the mean $\pm \operatorname{SEM}(n=5$ per group).

\section{Surface protein biotinylation}

Surface protein biotinylation on brain slices was performed following established protocols (Kato et al., 2012; Knackstedt et al., 2013; Pabba et al., 2014). Briefly, rat cerebellar slices $(300 \mu \mathrm{m})$ after drug treatments were incubated in ACSF containing $1 \mathrm{mg} / \mathrm{ml}$ EZ-LINK-SulfoNHS-SS-Biotin (Thermo Fisher Scientific) for $45 \mathrm{~min}$ at $4^{\circ} \mathrm{C}$. To biotinylate surface proteins of HEK293T cells, cells were incubated with EZ-LINK-Sulfo-NHS-SS-Biotin for $30 \mathrm{~min}$ at $4^{\circ} \mathrm{C}$. Unreacted biotinylation reagent was removed by washing and was quenched by $100 \mathrm{~mm}$ glycine. Slices and HEK293T cells were homogenized by sonication in an HEPES-Triton-SDS lysis buffer containing the following (in mM): 25 HEPES, $150 \mathrm{NaCl}, 1 \%$ Triton $\mathrm{X}-100,0.5 \%$ SDS, and a protease/phosphatase inhibitor cocktail (Thermo Fisher Scientific). After centrifugation $(1000 \times \mathrm{g}, 10 \mathrm{~min})$ at $4^{\circ} \mathrm{C}$, the supernatant was collected and used as the total protein fraction. An equal aliquot of total proteins was incubated with neutrAvidin resin (Thermo Fisher Scientific) overnight at $4^{\circ} \mathrm{C}$. Biotinylated proteins (i.e., surface proteins) were precipitated by centrifugation and were then eluted with an LDS sample buffer (boiling for $3 \mathrm{~min}$ ). The abundance of proteins of interest in surface and total fractions was analyzed by immunoblotting.

\section{Western blot}

To separate proteins, SDS NuPAGE Bis-Tris 4-12\% gels (Invitrogen) were used. Separated proteins were transferred to polyvinylidene fluoride membranes. We then incubated membranes with primary antibodies overnight at $4^{\circ} \mathrm{C}$, which was followed by incubation with secondary antibodies. An enhanced chemiluminescence reagent (GE Healthcare) was used to develop immunoblots.

\section{$\mathrm{IP}_{3}$ assays}

Intracellular $\mathrm{IP}_{3}$ levels in rat cerebellar slices or HEK293T cells were measured using a HitHunter $I_{3}$ Fluorescence Polarization Assay Kit from DiscoveRx or a rat 
A

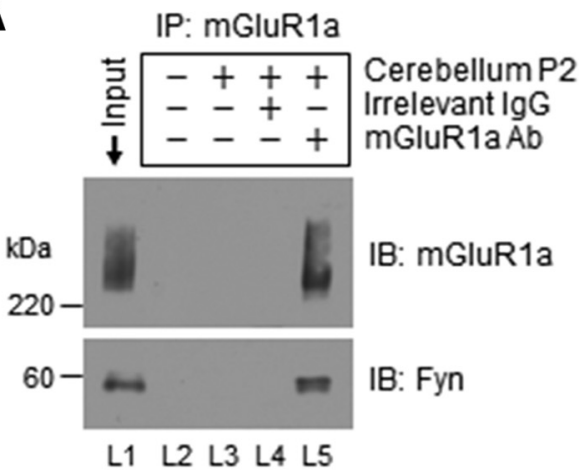

C

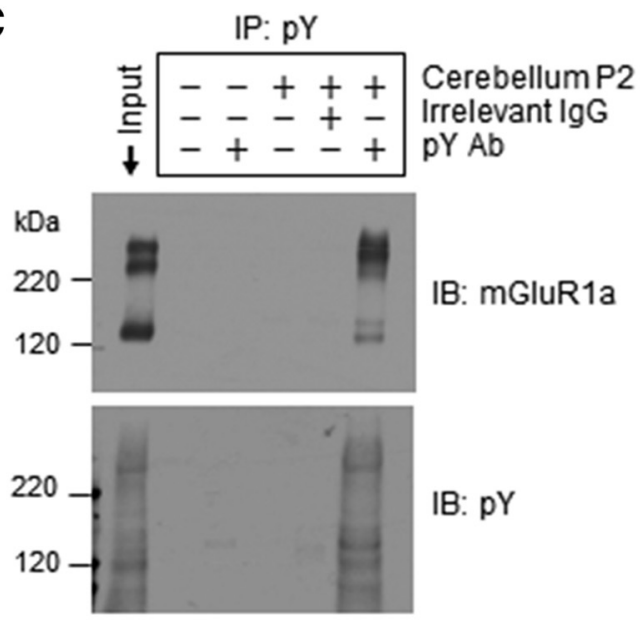

B

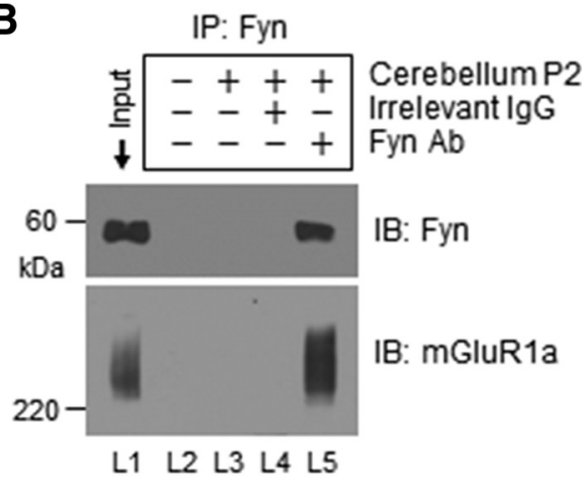

D
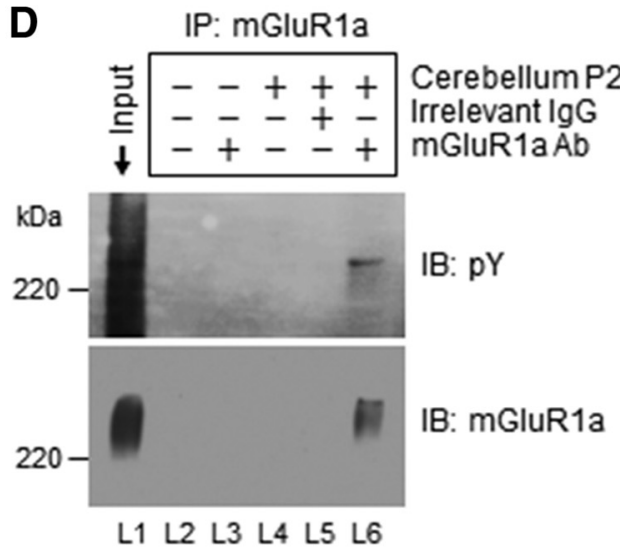

IB: pY

IB: mGluR1a

L1 L2 L3 L4 L5 L6

Figure 4. Coimmunoprecipitation of Fyn with mGluR1a and tyrosine phosphorylation of mGluR1a in rat cerebellar neurons. $\boldsymbol{A}$, Coimmunoprecipitation (IP) of Fyn and mGluR1a with an anti-mGluR1a antibody (Ab). B, Reverse coimmunoprecipitation of Fyn and mGluR1a with an anti-Fyn antibody. Note that Fyn and mGluR1a were seen in mGluR1a and Fyn precipitates, respectively (lane 5). No specific bands were seen in lanes 3 and 4 due to the lack of a precipitating antibody (L3) and the use of an irrelevant IgG (L4). C, Tyrosine-phosphorylated mGluR1a detected in immunoprecipitated pY proteins. Phosphotyrosine proteins were precipitated by an anti-pY antibody. mGluR1a was clearly seen in pY precipitates. $\boldsymbol{D}$, Tyrosine phosphorylation of mGluR1a detected in immunoprecipitated mGluR1a proteins. Solubilized synaptosomal proteins (P2) from the cerebellum were used in IP assays. Precipitated proteins were visualized by immunoblots (IB) with indicated antibodies.

IP3 ELISA kit from CUSABIO following the manufacturer instructions (Jin et al., 2013; Cansev et al., 2015; Tabatadze et al., 2015).

\section{Antibodies and pharmacological agents}

The antibodies we used in this study include rabbit antibodies against mGluR1a (Millipore), Src with phosphorylated tyrosine 416 (pan-pY416, Cell Signaling Technology), Fyn (Cell Signaling Technology), Src (Cell Signaling Technology), phosphotyrosine (pY; Millipore), Fak (Cell Signaling Technology), paxillin (Cell Signaling Technology), FLAG (Cell Signaling Technology), or $\beta$-actin (Sigma-Aldrich), or mouse antibodies against mGluR1a (BD), Fyn (Santa Cruz Biotechnology), pY (PY20, BD), or transferrin receptors (TfRs; Thermo Fisher Scientific). The antibody against pY416 reacts with the following Src family members when autophosphorylated at a conserved activation residue: Y416 (chicken Src), Y419 (rat Src), and Y420 (rat Fyn). Pharmacological agents, including (S)-3,5-dihydroxyphenylglycine (DHPG), 3-methyl-aminothiophene dicarboxylic acid (3-MATIDA), 3-(4-chlorophenyl) 1-(1,1-dimethylethyl)-1H-pyrazolo[3,4- d]pyrimidin-4-amine (PP2), 1-phenyl-1H-pyrazolo[3,4d] pyrimidin-4-amine (PP3), and oxotremorine-M, were purchased from Sigma-Aldrich. All drugs were freshly prepared on the day of the experiments.

\section{Statistics}

The results in this study are presented as the mean \pm SEM. Data were evaluated using the Student's $t$ test or a one-way ANOVA followed by a Bonferroni (Dunn) comparison of groups using least-squares-adjusted means. Probability levels of $<0.05$ were considered to be statistically significant.

\section{Results}

\section{Phosphorylation of mGluR1a by Fyn}

Intracellular domains of mGluR1a include IL1, IL2, IL3, and CT. Notably, only the CT region contains tyrosine residues. To explore possible phosphorylation at any of these tyrosine residues, we synthesized two GST fusion recombinant proteins covering the different segments of CT [i.e., mGluR1aCT1(K841-T1000) and mGluR1a-CT2(P1001-L1199)] in 

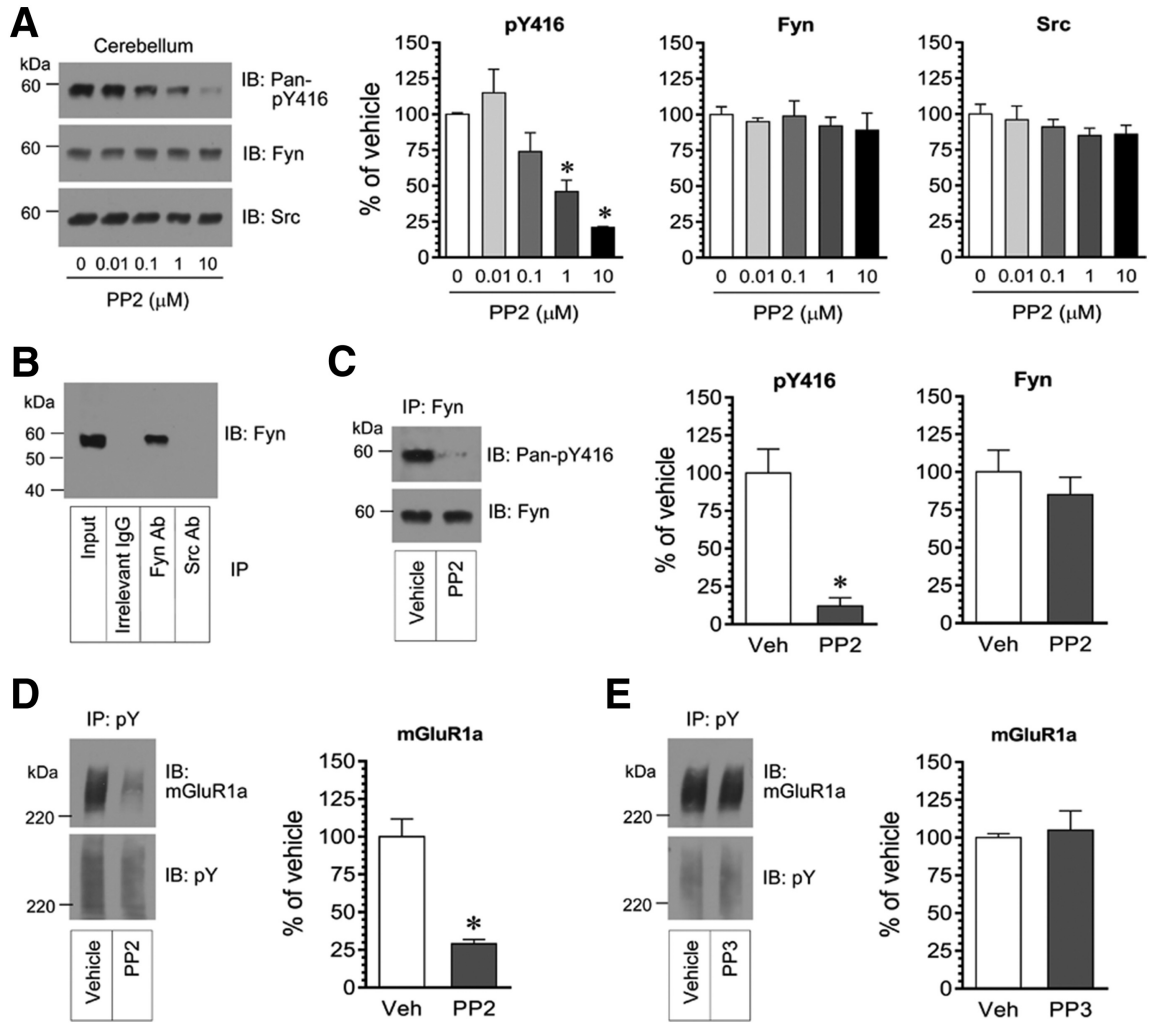

Figure 5. Tyrosine phosphorylation of mGluR1a in rat cerebellar neurons. A, Effects of PP2 on Y416 phosphorylation and expression of Fyn and Src in the cerebellum. Note that PP2 concentration-dependently reduced pan-pY416 levels, while PP2 did not affect Fyn and Src expression. $\boldsymbol{B}$, Immunoprecipitation of Fyn from the cerebellum. Cerebellar Fyn was immunopurified by a Fyn antibody but not by an Src antibody or irrelevant IgG. C, Effects of PP2 on Y416 phosphorylation of Fyn proteins immunopurified from the cerebellum. Note that Fyn Y416 phosphorylation was almost abolished by PP2. $\boldsymbol{D}, \boldsymbol{E}$, Effects of PP2 (D) and PP3 (E) on tyrosine phosphorylation of mGluR1a. Note that the amount of tyrosine-phosphorylated mGluR1a was drastically reduced by PP2 but not PP3. Tyrosine phosphorylation of mGluR1a was detected by immunoprecipitation of pY proteins, followed by immunoblot analysis of mGluR1a in pY precipitates. Representative immunoblots are shown to the left of the quantified data $(\boldsymbol{A}, \boldsymbol{C}-\boldsymbol{E})$. Rat cerebellar slices were incubated with vehicle (Veh), PP2, or PP3 at the range of concentrations indicated $(\boldsymbol{A})$ or at $10 \mu \mathrm{M}(\boldsymbol{C}-\boldsymbol{E})$ for 30 min. Slices were then collected for immunoblots (IB; $\boldsymbol{A})$ or immunoprecipitation (IP) followed by immunoblots $(\boldsymbol{B}-\boldsymbol{E})$. Data are presented as means \pm SEM ( $n=3-5$ per group) and were analyzed by one-way ANOVA $(\boldsymbol{A})$ or Student's $t$ test $(\boldsymbol{C}-\boldsymbol{E})$. $* p<0.05$ vs vehicle.

addition to a GST protein (Fig. 1A). These three proteins were then used for testing their tyrosine phosphorylation in response to active Fyn in phosphorylation assays in vitro. Using an anti-phosphotyrosine antibody, we found phosphorylation signals in GST-mGluR1a-CT1 but not GSTmGluR1a-CT2 and GST alone (Fig. 1B). Similarly, through monitoring the incorporation rate of ${ }^{32} \mathrm{P}$ into the proteins, we detected phosphorylation in CT1 but not CT2 (Fig. 1C). Stoichiometric ratios of $0.48 \pm 0.02$ and $0.89 \pm 0.05 \mathrm{~mol}$ phosphate/mol CT1 were obtained after 2 and $30 \mathrm{~min}$ of incubation, respectively. Phosphorylation was also seen in GST-GluA2-CT (Fig. 1D). Since the AMPA receptor GluA2 subunit is a known substrate of Fyn (Hayashi and Huganir, 2004), this phosphorylation response of GluA2-CT served as a positive control. These results reveal that mGluR1a is among the proteins subjected to tyrosine phosphorylation by Fyn. Consistent with this notion, Fyn failed to induce phosphorylation of CT1 in the absence of the phosphate donor ATP (Fig. 1E). The Fyn-induced phosphorylation of CT1 was dephosphorylated by a serine/threonine and tyrosine dual-specificity phosphatase CIP (Edbauer et al., 2009; Orlando et al., 2009; Fig. 1F). In addition, active Fyn phosphorylated GluA2-CT but not GluA1-CT of AMPA glutamate receptors (Fig. 1G), which is similar to the observations in a previous study (Hayashi and Huganir, 2004). Unlike Fyn, another nonreceptor tyrosine kinase Fak did not phosphorylate mGluR1a-CT1, while it phosphorylated its own known substrate paxillin (Panetti, 2002; Fig. 1H). Together, the results obtained above reveal mGluR1a as a new substrate of Fyn.

There are two tyrosine sites in mGluR1a-CT1: tyrosine 937 (Y937) and tyrosine 955 (Y955; Fig. 2A). We next tested the phosphorylation response of these two sites to Fyn to identify the accurate phosphorylation site. To this end, we synthesized CT1 proteins carrying site-directed mutations (Fig. 2B). We then compared these mutants with WT CT1 in phosphorylation reactions. Noticeably, the mutation of Y937 to phenylalanine (mutation 1, Y937F) abolished CT1 phosphorylation as detected by ${ }^{32} \mathrm{P}$ incorporation (Fig. 2C). In contrast, the mutation of Y955 (mutation 2, Y955F) did not affect CT1 phosphorylation. No phosphorylation was detected in the mutant bearing mutations in both sites (mutation 3, Y937/955F). Similar results were observed in assays in which phosphorylation 
A

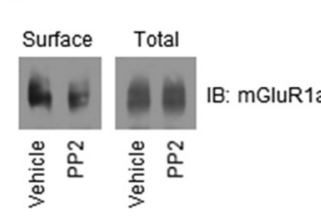

B

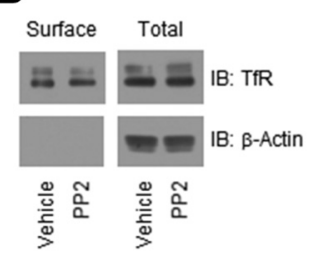

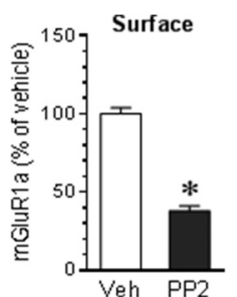

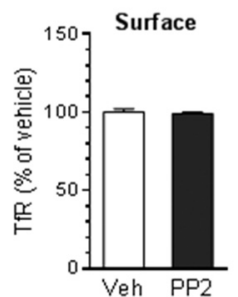

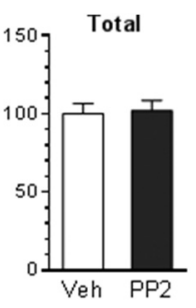

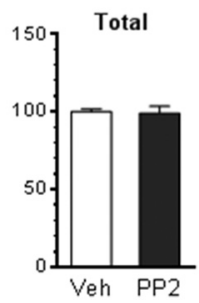

Figure 6. Effects of SFK inhibition on surface expression of mGluR1a in rat cerebellar neurons. $\boldsymbol{A}$, Effects of the SFK inhibitor PP2 on the surface expression of mGluR1a. Note that PP2 reduced surface levels of mGluR1a, while PP2 did not alter a total amount of mGluR1a. B, Effects of the SFK inhibitor PP2 on the surface expression of TfR. Representative immunoblots are shown to the left of the quantified data. Cerebellar slices were incubated with vehicle (Veh) or PP2 (10 $\mu \mathrm{M}, 30 \mathrm{~min})$. Slices were then collected for surface protein biotinylation followed by immunoblot (IB) analysis of the amount of mGluR1a in surface and total protein fractions. Data are presented as the mean \pm SEM ( $n=6$ per group) and were analyzed by Student's $t$ test. $* p<$ 0.05 vs vehicle.

responses were detected by an anti-pY antibody (Fig. 2D). Evidently, Y937 is a primary site subjected to phosphorylation by Fyn, while Y955 is insensitive to Fyn. Amino acid alignment analysis reveals conservation of Y937 in the human, rat, and mouse mGluR1a (Fig. 2E).

\section{Binding activity between Fyn and mGluR1a}

Fyn binds to many of its known substrates (Knox and Jiang, 2015). To determine whether Fyn binds to mGluR1a, we conducted a series of protein-protein binding assays. In these assays, we used GST fusion proteins containing discrete intracellular domains of mGluR1a as immobilized molecules to precipitate a target binding partner [i.e., Fyn]. In pull-down assays, GST-mGluR1a-CT1 precipitated native Fyn from adult rat cerebellar lysates, while GST alone and other GST fusion proteins containing IL1, IL2, IL3, and CT2 did not (Fig. $3 A$ ). No GST fusion proteins precipitated Fak (Fig. $3 A$ ). Fyn is predominantly expressed in the cerebellum (Umemori et al., 1992; Bare et al., 1993), and meanwhile Fak is also expressed in this region (Burgaya et al., 1995; Menegon et al., 1999). To determine whether Fyn directly binds to mGluR1a, we performed in vitro binding assays with purified Fyn and mGluR1a proteins. GST-mGluR1a-CT1 bound to and precipitated Fyn (Fig. 3B). GST alone and other GST fusion proteins showed no precipitation of Fyn. Fak was not precipitated by any GST fusion proteins (Fig. 3C). GST-Fak precipitated its known substrate paxillin (Fig. 3D). These results support that Fyn binds to mGluR1a at the CT1 region of the receptor.

We next compared active and inactive Fyn for their binding activity to mGluR1a-CT1. As shown in Figure 3E,

a constitutively active form of Fyn (i.e., Fyn-Y531F; Cheng et al., 1991), bound to CT1. So did an inactive form of Fyn [i.e., a kinase-dead and dominant-negative mutant of Fyn (K299M); Twamley et al., 1992; Twamley-Stein et al., 1993]. The inactive form of K299M was confirmed by the lack of phosphorylation at a conserved and activationassociated autophosphorylation site (Y416; Roskoski, 2005; Okada, 2012). To further narrow down the binding region, we tested different parts of $\mathrm{CT} 1$ in their binding activity to Fyn. CT1c (N925-T1000) precipitated Fyn (Fig. $3 F$ ). In contrast, CT1a (K841-N885) and CT1b (A886K931) did not. Thus, CT1c is a core region harboring Fyn. Interestingly, the Fyn-mediated phosphorylation site Y937 resides within this region. Adjacent to Y937, there are three consensus proline-rich motifs (PXXP, where " $X$ " represents any amino acid; Fig. $3 G$ ) where Fyn could bind via its Src-homology 3 (SH3) domain (Ren et al., 1993; Hauck et al., 2001), a highly conserved platform among SFKs for protein-protein interactions (Saito et al., 2010). As expected, CT1c, but not CT1a and CT1b fragments, was tyrosine phosphorylated by Fyn (Fig. 3H).

\section{Interactions of Fyn with mGluR1a in cerebellar neurons}

Our next attempt was to determine whether Fyn interacts with mGluR1a in neurons. This was examined in coimmunoprecipitation assays using the rat cerebellar tissue because mGluR1 but not mGluR5 is expressed in the cerebellum (Martin et al., 1992; Shigemoto et al., 1993) and Purkinje neurons, the principal neurons of cerebellar cortex, express mGluR1a as a predominant splice variant (Fotuhi et al., 1993). In a coimmunoprecipitation assay in which an anti-mGluR1a antibody was added into solubilized synaptosomal protein samples (P2), we observed strong mGluR1a immunoreactivity (Fig. 4A). Noticeably, Fyn immunoreactivity was also exhibited in mGluR1a precipitates, indicating that endogenous Fyn and mGluR1a form complexes in cerebellar neurons in vivo. This notion is supported by a reverse coimmunoprecipitation assay in which an anti-Fyn antibody was added to precipitate Fyn. mGluR1a immunoreactivity was seen in Fyn precipitates (Fig. 4B). To determine whether native mGluR1a in cerebellar neurons is tyrosine phosphorylated, we immunoprecipitated $\mathrm{pY}$ proteins from the cerebellum using an anti-pY antibody. In this defined pool of pY proteins, we found a detectable amount of mGluR1a (Fig. 4C). In immunoprecipitated mGluR1a proteins, we also saw $\mathrm{pY}$ signals (Fig. 4D). Thus, mGluR1a in cerebellar neurons is among a subset of proteins subjected to tyrosine phosphorylation under normal conditions.

\section{Phosphorylation of cerebellar mGluR1a by SFKs}

To determine whether tyrosine phosphorylation of mGluR1a in cerebellar neurons is mediated by SFKs, we investigated the impact of inhibition of SFKs on mGluR1a tyrosine phosphorylation. To inhibit SFKs, we used a widely used SFK inhibitor, PP2 (Hanke et al., 1996). We first evaluated the efficacy and potency of PP2 in inhibiting SFKs in a concentration-response study in rat cerebellar slices. Adding PP2 $(0.01,0.1,1$, and $10 \mu \mathrm{M}, 30 \mathrm{~min})$ 

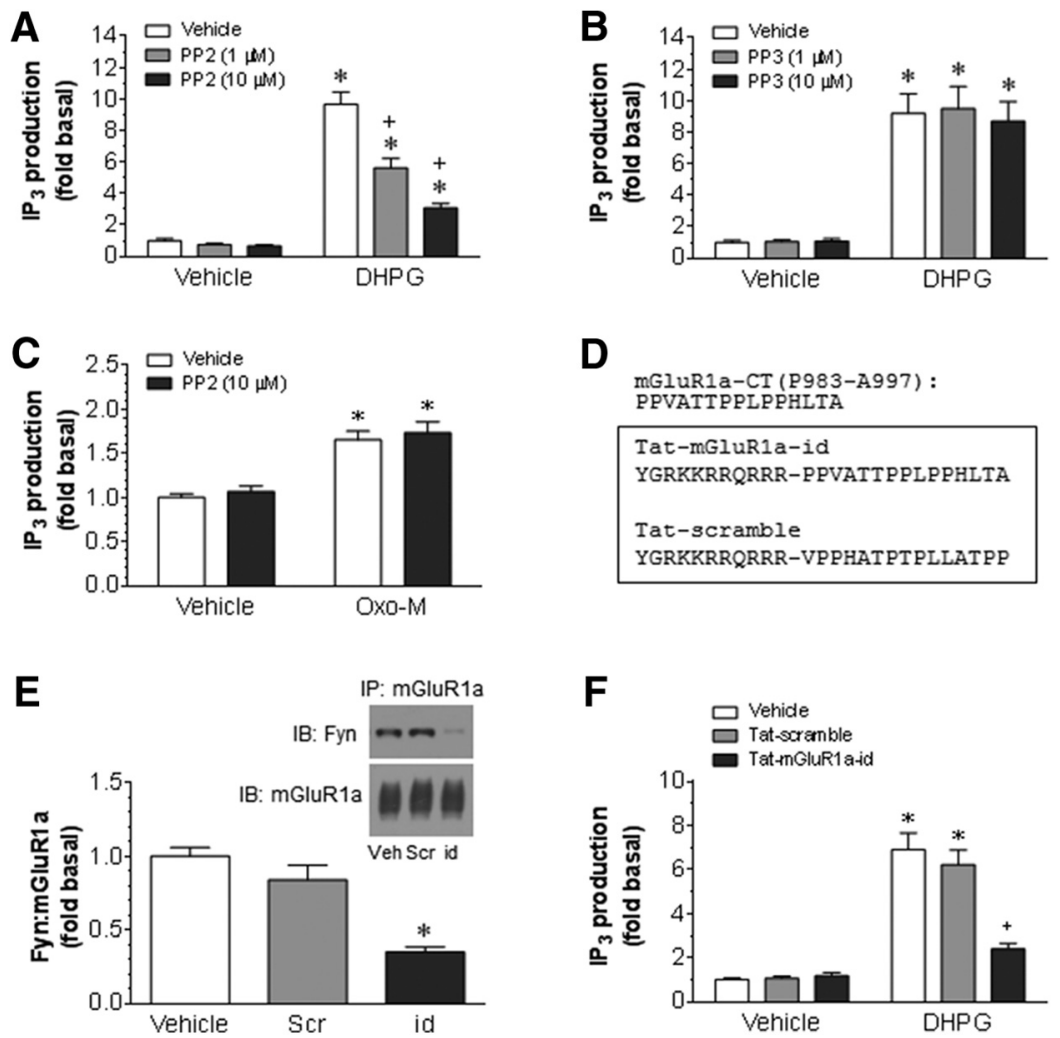

Figure 7. Effects of inhibition of SFKs or disruption of Fyn-mGluR1a interactions on the mGluR1-mediated IP 3 production in rat

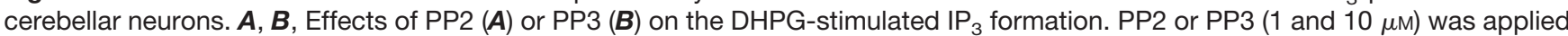
30 min before and during $20 \mathrm{~s}$ incubation of DHPG $(50 \mu \mathrm{M})$. Note that PP2 reduced IP 3 responses to DHPG, while PP3 did not. Both

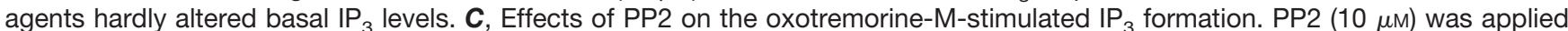
$30 \mathrm{~min}$ before and during $20 \mathrm{~s}$ incubation of oxotremorine-M (Oxo-M; $10 \mu \mathrm{M})$. D , Synthesized Tat fusion peptides. E, Effects of Tat peptides on the interaction between Fyn and mGluR1a. $\boldsymbol{F}$, Effects of Tat peptides on the DHPG-stimulated IP 3 formation. Vehicle (Veh), Tat-mGluR1a-id (id), or Tat-scramble (Scr) at $10 \mu \mathrm{m}$ was applied alone for $45 \mathrm{~min}(\boldsymbol{E})$ or 45 min before and during $20 \mathrm{~s}$ incubation of $50 \mu \mathrm{M}$ DHPG $(\boldsymbol{F})$. Note that Tat-mGluR1a-id markedly reduced the interaction of Fyn with mGluR1a $(\boldsymbol{E})$ and the IP $\mathrm{P}_{3}$ response to DHPG $(\boldsymbol{F})$, while Tat-scramble did not. Experiments were conducted in rat cerebellar slices. Data are presented as the mean \pm SEM ( $n=6$ /group) and were analyzed by one-way ANOVA. $* p<0.05$ vs vehicle $(\boldsymbol{E})$ or vehicle plus vehicle $(\boldsymbol{A}-\boldsymbol{C}, \boldsymbol{F}) .+p<0.05$ vs vehicle plus DHPG $(\boldsymbol{A}, \boldsymbol{F})$.

greatly reduced the phosphorylation of SFKs at Y416, while PP2 had no effect on a total amount of Fyn or Src (Fig. 5A). This effect was clearly concentration dependent. To test the effect of PP2 on specific Fyn, we immunoprecipitated Fyn proteins from the cerebellum after PP2 treatment (Fig. 5B). We then analyzed changes in pY416 signals in the immunoprecipitated fraction of Fyn proteins. PP2 (10 $\mu \mathrm{M}, 30 \mathrm{~min})$ substantially reduced the pY416 level of Fyn (Fig. 5C). PP2, however, did not alter total Fyn expression. These results establish an effective concentration of PP2 in inhibiting Fyn in our brain slice model. We then used this concentration to examine the effect of PP2 on mGluR1a tyrosine phosphorylation.

Adding PP2 to cerebellar slices (10 $\mu \mathrm{M}, 30 \mathrm{~min})$ considerably reduced tyrosine phosphorylation of mGluR1a. As shown in Figure $5 D$, mGluR1a immunoreactivity in $\mathrm{pY}$ precipitates was largely reduced in PP2-treated slices compared with vehicle control slices. In contrast, PP3, an inactive analog of PP2, did not alter mGluR1a levels in $\mathrm{PY}$ precipitates (Fig. 5E). Thus, a PP2-sensitive SFK acts as a central kinase responsible for maintaining constitutive tyrosine phosphorylation of mGluR1a in cerebellar neurons.

\section{Roles of SFKs in regulating surface expression of mGluR1a}

Tyrosine phosphorylation of mGluR1a by Fyn may have an impact on surface expression of the receptors. To evaluate this, we investigated whether PP2 alters surface levels of mGluR1a. A surface protein biotinylation protocol was used to monitor changes in the surface expression of mGluR1a (see Materials and Methods). In rat cerebellar slices, the application of PP2 (10 $\mu \mathrm{M}, 30 \mathrm{~min})$ markedly reduced the amount of mGluR1a in the surface fraction (Fig. 6A). The total cellular levels of mGluR1a were not altered. A surface protein, the TfR, and an intracellular protein, $\beta$-actin, were measured as a surface and intracellular protein control, respectively. As shown in Figure $6 B$, TfRs were densely seen in surface and total fractions, whereas $\beta$-actin was not shown in surface fractions, demonstrating the selectivity of our biotinylation method in cross-linking surface proteins. No significant change in the surface levels of TfRs was seen following PP2 incubation (Fig. 6B). These results indicate a significant role of SFKs in determining the number of mGluR1a in the surface compartment of cerebellar neurons. 

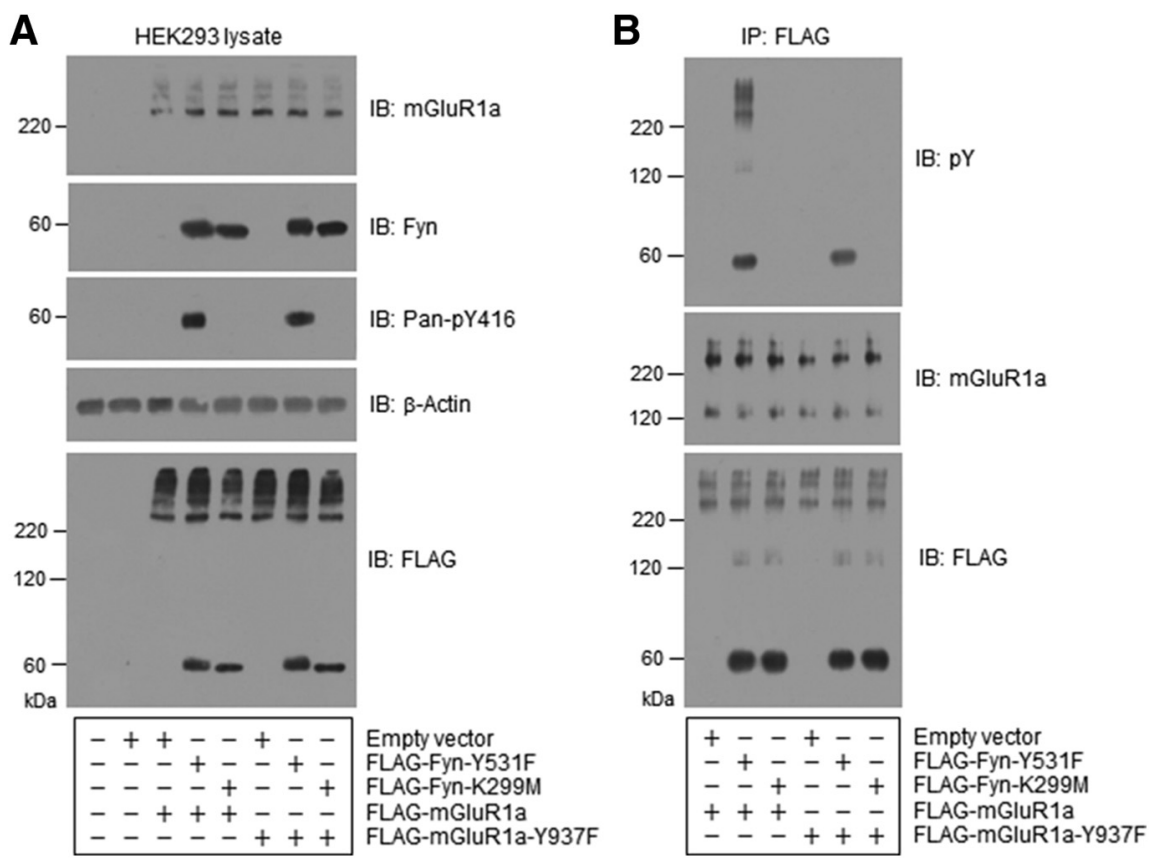

Figure 8. Fyn-induced phosphorylation of mGluR1a at Y937 in HEK293T cells. $\boldsymbol{A}$, Representative immunoblots illustrating the expression of mGluR1a (WT and Y937F) and Fyn (Y531F and K299M) transfected in HEK293T cells. B, Tyrosine phosphorylation of mGluR1a by cotransfection of active Fyn in HEK293T cells. Note that tyrosine phosphorylation of mGluR1a was seen in HEK293T cells cotransfected with active Fyn (Y531F) but not inactive Fyn (K299M). Such phosphorylation occurred to WT mGluR1a but not to mGluR1a-Y937F. FLAG-tagged mGluR1a (WT and Y937F) and FLAG-tagged Fyn (Y531F and K299M) in pcDNA3.1 + C(K)DYK vectors (empty vectors) were transfected or cotransfected in HEK293T cells. FLAG-tagged proteins were purified via immunoprecipitation (IP) with an anti-FLAG antibody. Transfected and immunopurified proteins were analyzed by immunoblots (IB).

\section{Roles of SFKs in regulating mGluR1-IP 3 signaling}

To further explore the functional roles of tyrosine phosphorylation of mGluR1, we investigated the effect of PP2 on the mGluR1-associated signaling activity. Activation of mGluR1 increases phosphoinositide hydrolysis, yielding a key signaling molecule, $\mathrm{IP}_{3}$ (Niswender and Conn, 2010; Traynelis et al., 2010). We thus measured the mGluR1induced $\mathrm{IP}_{3}$ yield as function of mGluR1. DHPG, an mGluR1/5 agonist, induced a typical increase in cytosolic $\mathrm{IP}_{3}$ levels after it was added to cerebellar slices $(50 \mu \mathrm{M}, 20$ s; Fig. 7A). This increase was completely blocked by an mGluR1-selective antagonist, 3-MATIDA (10 $\mu \mathrm{M}$; data not shown), verifying the role of mGluR1 in mediating the DHPG-stimulated $\mathrm{IP}_{3}$ production. Pretreatment with PP2 (1 $\mu \mathrm{M}, 30$ min before DHPG) significantly reduced $\mathrm{IP}_{3}$ responses to DHPG. A greater reduction in $\mathrm{IP}_{3}$ responses was seen following pretreatment with PP2 at a higher concentration $(10 \mu \mathrm{M})$. In contrast to PP2, PP3 at two concentrations ( 1 and $10 \mu \mathrm{M}$ ) had no significant influence over $\mathrm{IP}_{3}$ responses to DHPG (Fig. 7B). Neither PP2 nor PP3 altered basal levels of $I P_{3}$. These results indicate that the inhibition of SFKs leads to a reduction in mGluR1mediated $\mathrm{IP}_{3}$ production.

Muscarinic acetylcholine receptors (mAChRs) are expressed in the cerebellum (Whitham et al., 1991; Tayebati et al., 2001; Billups et al., 2006). Of the five mAChR subtypes, M1, M3, and M5 subtypes are $G_{\alpha q}$-coupled receptors and are linked to the activation of PLC $\beta 1$ (Felder, 1995; Wess, 1996). The activation of $G_{\alpha q}$-coupled mAChRs, predominantly M3 receptors, present on cerebellar Purkinje neurons with a mAChR agonist oxotremorine-M blocked long-term potentiation at cerebellar parallel fiber-Purkinje cell synapses (Rinaldo and Hansel, 2013). In this study, we found that oxotrmorine-M $(10 \mu \mathrm{M}, 20 \mathrm{~s})$ elevated $\mathrm{IP}_{3}$ levels in cerebellar slices (Fig. 7C). This elevation was not affected by PP2. Thus, SFK activity is not involved in the regulation of $\mathrm{IP}_{3}$ responses to $\mathrm{mAChR}$ activation.

We next synthesized a cell-permeable, Tat-fusion peptide that contains the proline-rich motifs (PXXP) in the CT1C fragment (Fig. 7D). This peptide was designed to interfere with the Fyn-mGluR1a interaction and was thus named as an interaction-dead (Tat-mGluR1a-id) peptide. In fact, the application of Tat-mGluR1a-id (10 $\mu \mathrm{M}, 45 \mathrm{~min})$ significantly reduced the interaction of Fyn with mGluR1a in cerebellar slices, while a sequence-scrambled control peptide (Tat-scramble) did not (Fig. 7E). This establishes the importance of these proline-rich motifs for the binding of Fyn to mGluR1a. Of note, Tat-mGluR1a-id reduced the $I_{3}$ response to DHPG, while Tat-scramble had no effect (Fig. 7F). Thus, the Fyn-mGluR1a interaction is critical for the mGluR1a-IP ${ }_{3}$ signaling.

\section{Fyn regulates mGluR1a in HEK293T cells}

The role of Fyn in phosphorylating and regulating mGluR1a was further analyzed in HEK293T cells. FLAGtagged mGluR1a (WT or Y937F, a phosphorylationdeficient mutant due to the mutation of tyrosine 937 to phenylalanine) and Fyn (Y531F or K299M) were readily transfected in HEK293T cells (Fig. 8A). The amount of total mGluR1a protein (WT or Y937F) seemed to remain 
A

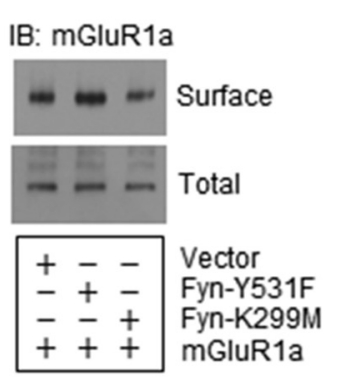

D

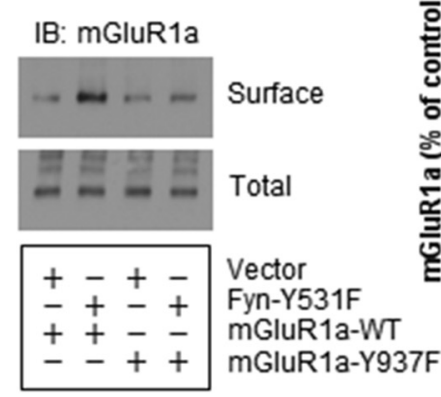

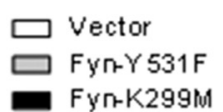

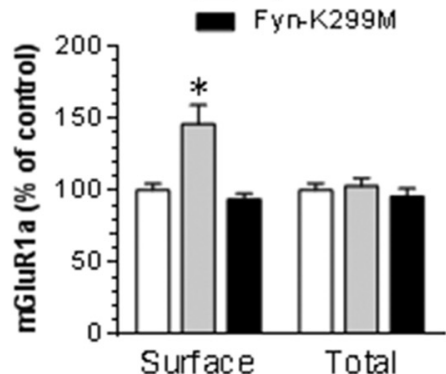

B

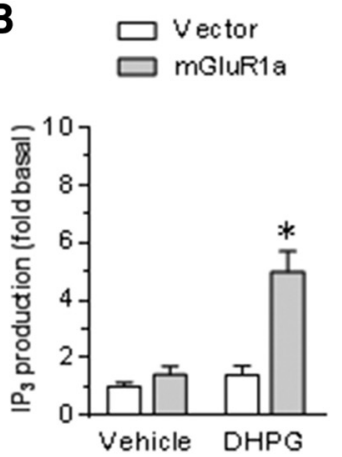

C $\square$ vector

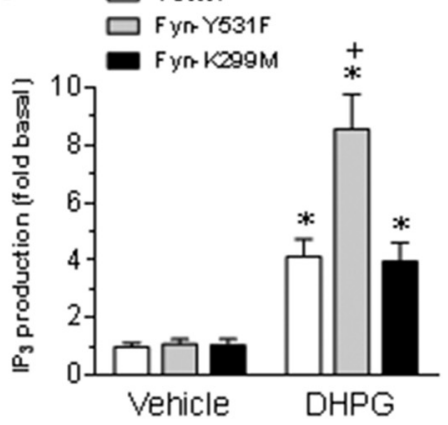

Surface

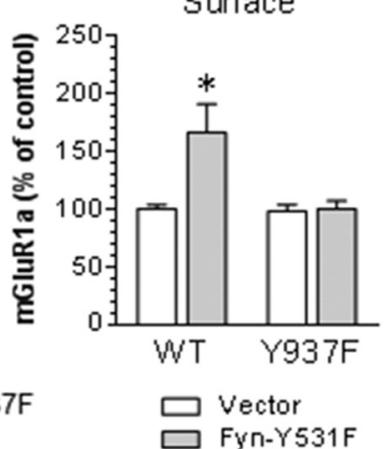

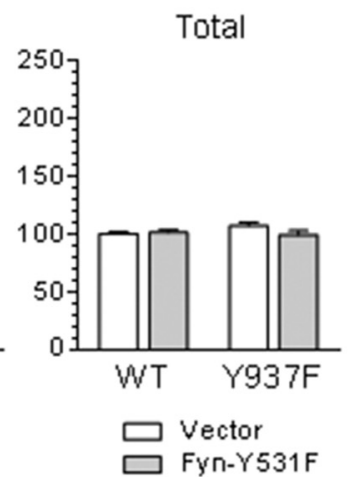

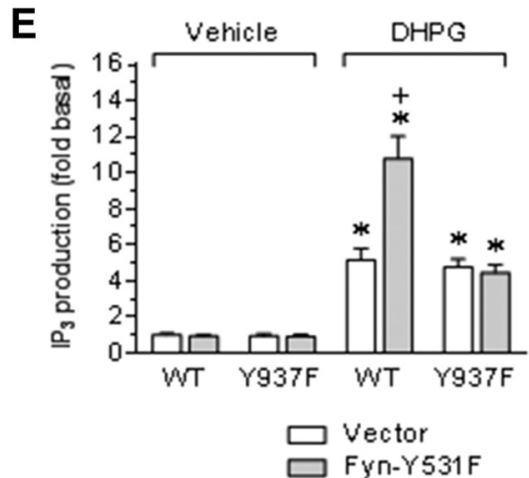

Figure 9. Surface expression of mGluR1a and agonist-stimulated IP 3 production in HEK293T cells. $\boldsymbol{A}$, Effects of cotransfection of Fyn on the surface expression of mGluR1a. mGluR1a was cotransfected with active (Y531F) or inactive (K299M) Fyn. Note that surface expression of mGluR1a was elevated by cotransfection with Y531F but not K299M. B, DHPG-stimulated IP 3 production in HEK293T cells transfected with mGluR1a. C, DHPG-stimulated IP $_{3}$ production in HEK293T cells cotransfected with mGluR1a and active and inactive Fyn. Note that the DHPG-stimulated IP 3 production was enhanced by cotransfection with Y531F but not K299M. $\boldsymbol{D}$, Effects of the site-directed mutation at mGluR1a-Y937 on the Fyn-induced surface expression of mGluR1a. mGluR1a WT or Y937 phosphorylation-deficient mutant (Y937F) was cotransfected with active Fyn (Y531F). Note that the mutation of Y937 abolished the active Fyn-induced increase in surface expression of mGluR1a. $\boldsymbol{E}$, Effects of the site-directed mutation at mGluR1a-Y937 on the Fyn-induced increase in $\mathrm{IP}_{3}$ responses to DHPG. Note that cotransfection with active Fyn (Y531F) augmented IP 3 responses to DHPG in HEK293T cells cotransfected with WT but not Y937F mGluR1a. Representative immunoblots are shown to the left of the quantified data $(\boldsymbol{A}, \boldsymbol{D})$. Proteins were visualized by immunoblots (IB). In IP 3 assays, DHPG (50 $\mu \mathrm{M})$ was added and cells were collected $20 \mathrm{~s}$ after DHPG incubation. Data are presented as the mean \pm SEM $(n=3-6 /$ group $)$ and were analyzed by one-way ANOVA. $* p<0.05$ vs vector $(\boldsymbol{A}, \boldsymbol{B}, \boldsymbol{D})$ or vector plus vehicle $(\boldsymbol{C}, \boldsymbol{E}) .+p<0.05$ vs vector plus DHPG $(\boldsymbol{C}, \boldsymbol{E})$.

stable after cotransfected with either the constitutively active Fyn (Y531F) or inactive Fyn (K299M). The active and inactive states of Fyn-Y531F and Fyn-K299M, respectively, were confirmed by the detection of pY416 signals in Fyn-Y531F but not Fyn-K299M. Remarkably, tyrosine phosphorylation of mGluR1a at Y937 was induced by active Fyn. As shown in Figure 8B, pY signals were detected in FLAG-tagged proteins immunopurified by an anti-FLAG antibody when WT mGluR1a was cotransfected with Fyn-Y531F but not Fyn-K299M. These pY signals were lacking in HEK293T cells transfected with the mGluR1a-Y937 phosphorylation-deficient mutant (Y937F). These results reveal that active Fyn phosphorylates mGluR1a at Y937 in a heterologous expression system.

To determine the role of Fyn in regulating the surface expression of mGluR1a, we cotransfected active or inactive Fyn with mGluR1a in HEK293T cells. We found that active Fyn (i.e. Y531F) significantly increased mGluR1a surface expression, while inactive Fyn (K299M) did not (Fig. 9A). Both active and inactive Fyn did not change the level of total mGluR1a proteins. Thus, in transfected HEK293T cells, Fyn enhances the surface expression of mGluR1a.

We next determined whether Fyn regulates mGluR1a signaling. $\mathrm{IP}_{3}$ production was measured as a readout of mGluR1a signaling. DHPG induced an increase in $\mathrm{IP}_{3}$ levels in HEK293T cells transfected with mGluR1a, but not with an empty vector (Fig. 9B), indicating successful expression of functional mGluR1a in HEK293T cells. When mGluR1a was cotransfected with a Fyn mutant, active Fyn (Y531F) significantly augmented $\mathrm{IP}_{3}$ responses to DHPG, while inactive Fyn (K299M) did not (Fig. 9C). This indicates that Fyn positively regulates mGluR1a signaling in transfected HEK293T cells.

To examine whether Fyn regulates mGluR1a via phosphorylating Y937, we conducted a site-directed mutation study. A phosphorylation-deficient mutant of mGluR1a (Y937F) was cotransfected with active Fyn (Y531F) in HEK293T cells. The effects of Fyn-Y531F on surface expression and signaling activity of mGluR1a were then examined in transfected HEK293T cells. WT mGluR1a 
and mGluR1a-Y937F exhibited a similar level of surface and total expression (Fig. 9D). However, active Fyninduced increases in surface expression of mGluR1a were seen only in WT, but not mutant mGluR1a (Y937F), indicating that $Y 937$ phosphorylation is critical for this event. In $\mathrm{IP}_{3}$ assays, the Y937F mutation completely abolished an augmentation of $\mathrm{IP}_{3}$ responses to DHPG induced by the cotransfection of active Fyn (Fig. 9E). These results support that the phosphorylation of mGluR1a at Y937 is essential for Fyn to enhance mGluR1a signaling.

\section{Discussion}

This study was conducted to explore a new substrate of Fyn. We found that an mGluR subtype, mGluR1a, is a target of Fyn. Fyn directly bound to mGluR1a CT in vitro. Similarly, endogenous and synapse-enriched Fyn interacted with mGluR1a in rat cerebellar neurons. Active Fyn phosphorylated mGluR1a at a conserved tyrosine site (Y937) in the CT region. This phosphorylation was constitutively active. The phosphorylation at Y937 was an important step for promoting surface expression of mGluR1a. By regulating surface expression of the receptor, Fyn controlled the mGluR1a-associated signaling transduction. In sum, the results obtained in vitro and in vivo support mGluR1a as a novel synaptic substrate of Fyn. Through directly binding to and phosphorylating mGluR1a, Fyn regulates mGluR1a in surface expression and postreceptor signaling.

The Fyn-mGluR1a interaction is a new model discovered in this study. This interaction is characterized by occurring in mGluR1a CT, a region thought to be a major protein-protein interaction area. Indeed, mGluR1a CT is relatively large and is a binding domain for most mGluR1a-interacting partners so far identified (Enz, 2012; Fagni, 2012). As to the specific binding site in mGluR1a CT, proline-rich PXXP motifs that are preferentially recognized by a protein-protein interaction module ( $\mathrm{SH} 3$ domain) of Fyn (Ren et al., 1993) exist in the CT1c region. Consistent with this, CT1c but not CT1a and CT1 b bound to Fyn. Thus, a PXXP-containing zone in CT1c likely harbors a binding site to Fyn. This is supported by the finding that a PXXP-containing peptide derived from mGluR1a$\mathrm{CT} 1 \mathrm{c}$ reduced the association between Fyn and mGluR1a in cerebellar neurons (this study). In addition to the binding site in the CT region, tyrosine phosphorylation of mGluR1a induced by Fyn occurred at a residue (Y937) within the CT1c. Thus, the CT1c is a major region that Fyn interacts with to tyrosine phosphorylate and regulate the receptor.

Another important characteristic of the Fyn-mGluR1a coupling is its constitutively active nature. Following the demonstration of the binding between recombinant Fyn and mGluR1a proteins and tyrosine phosphorylation of mGluR1a in vitro, we investigated the interaction between two native proteins in neurons. In cerebellar neurons expressing Fyn (Umemori et al., 1992; Bare et al., 1993; Cioni et al., 2013) and mGluR1a (Martin et al., 1992; Shigemoto et al., 1993), the Fyn-mGluR1a complex was detected under basal conditions. In parallel with the basal Fyn-mGluR1a interaction, the Fyn-mediated tyrosine phosphorylation of mGluR1a occurred significantly under normal conditions. More importantly, the constitutively active phosphorylation is functionally relevant and contributes to the regulation of surface expression and signaling of mGluR1a under normal conditions (see below).

Fyn is enriched at synaptic sites and is conceived to play a critical role in regulating local synaptic proteins (Ohnishi et al., 2011; Schenone et al., 2011). Several substrates and binding partners of Fyn have been previously discovered at synaptic sites. Central among them is the NMDA glutamate receptor (Suzuki and Okumura-Noji, 1995; Köhr and Seeburg, 1996; Trepanier et al., 2012; Knox and Jiang, 2015). In addition, two prominent synaptic scaffold proteins, PSD-95 and PSD-93, are substrates of Fyn (Nada et al., 2003; Du et al., 2009). This study adds mGluR1a as another synaptic substrate of Fyn. The results from a series of biochemical and functional studies conducted in the present work are consistent with a notion that mGluR1a is subjected to the tyrosine phosphorylation and regulation by Fyn.

Phosphorylation is an important mechanism for the regulation of GPCRs. As a typical GPCR, mGluR1 is subjected to the regulation by a phosphorylationdependent mechanism. Several common protein kinases have been implicated in this event (Dhami and Ferguson, 2006; Kim et al., 2008; Mao et al., 2008). For example, PKC is involved in the phosphorylation and regulation of mGluR1 based on a number of early studies (Manzoni et al., 1990; Catania et al., 1991; Thomsen et al., 1993; Alaluf et al., 1995; Medler and Bruch, 1999; Francesconi and Duvoisin, 2000). calcium/calmodulin-dependent protein kinase II (CaMKII) is another kinase that contributes to the regulation of mGluR1a. By phosphorylating threonine 871 near the G-protein-coupling domain of mGluR1a (Dhami and Ferguson, 2006), CaMKII serves as an important element in forming a feedback loop that facilitates the agonist-induced desensitization of mGluR1a in striatal neurons (Jin et al., 2013). However, both PKC and CaMKII catalyze phosphorylation at serine and threonine residues. Whether a kinase that phosphorylates proteins at a tyrosine site is involved in the regulation of mGluR1 is unclear. This study provides evidence supporting a new tyrosine kinase-GPCR model that a synapse-enriched tyrosine kinase Fyn acts as a key regulator of mGluR1. However, unlike the activity-dependent and inhibitory nature of the regulation of mGluR1a by PKC and CaMKII, Fyn functions significantly under basal conditions and facilitates the receptors in their expression and postreceptor signaling. More specifically, in cerebellar neurons where mGluR1a and Fyn are predominantly expressed (Umemori et al., 1992; Bare et al., 1993; Fotuhi et al., 1993), Fyn constitutively binds to the largest intracellular domain of mGluR1a, which may serve to accumulate the kinase at synaptic sites under basal conditions. Synaptic Fyn then phosphorylates a tyrosine residue in mGluR1a to promote steady-state surface expression of the receptors and thereby maintain the activity level of mGluR1a signaling. Fyn may regulate trafficking, endocytosis, dimerization, or other steps important for surface expression of mGluR1a to modulate the number of the receptors in the 
surface compartment, although exact underlying mechanisms are unclear at present. Future studies need to clarify accurate mechanisms underlying the impact of the Fyn phosphorylation of mGluR1a on the surface expression of the receptors.

\section{References}

Alaluf S, Mulvihill ER, Mcllhinney RA (1995) Rapid agonist mediated phosphorylation of the metabotropic glutamate receptor $1 \alpha$ by protein kinase $\mathrm{C}$ in permanently transfected BHK cells. FEBS Lett 367:301-305. CrossRef

Bare DJ, Lauder JM, Wilkie MB, Maness PF (1993) p59fyn in rat brain is localized in developing axonal tracts and subpopulations of adult neurons and glia. Oncogene 8:1429-1436. Medline

Billups D, Billups B, Challiss RA, Nahorski SR (2006) Modulation of Gq-protein-coupled inositol trisphosphate and $\mathrm{Ca}^{2+}$ signaling by the membrane potential. J Neurosci 26:9983-9995. CrossRef Medline

Burgaya F, Menegon A, Menegoz M, Valtorta F, Girault JA (1995) Focal adhesion kinase in rat central nervous system. Eur $\mathrm{J}$ Neurosci 7:1810-1821. Medline

Cansev M, Orhan F, Yaylagul EO, Isik E, Turkyilmaz M, Aydin S, Gumus A, Sevinc C, Coskun N, Ulus IH, Wurtman RJ (2015) Evidence for the existence of pyrimidinergic transmission in rat brain. Neuropharmacology 91:77-86. CrossRef Medline

Catania MV, Aronica E, Sortino MA, Canonico PL, Nicoletti F (1991) Desensitization of metabotropic glutamate receptors in neuronal cultures. J Neurochem 56:1329-1335. Medline

Cheng SH, Espino PC, Marshall J, Harvey R, Merrill J, Smith AE (1991) Structural elements that regulate pp59c-fyn catalytic activity, transforming potential, and ability to associate with polyomavirus middle-T antigen. J Virol 65:170-179. Medline

Cioni JM, Telley L, Saywell V, Cadilhac C, Jourdan C, Huber AB, Huang JZ, Jahannault-Talignani C, Ango F (2013) SEMA3A signaling controls layer-specific interneuron branching in the cerebellum. Curr Biol 23:850-861. CrossRef Medline

Cooke MP, Perlmutter RM (1989) Expression of a novel form of the fyn proto-oncogene in hematopoietic cells. New Biol 1:66-74. Medline

Dhami GK, Ferguson SS (2006) Regulation of metabotropic glutamate receptor signaling, desensitization and endocytosis. Pharmacol Ther 111:260-271. CrossRef Medline

Du CP, Gao J, Tai JM, Liu Y, Qi J, Wang W, Hou XY (2009) Increased tyrosine phosphorylation of PSD-95 by Src family kinase after brain ischaemia. Biochem J 417:277-285. CrossRef Medline

Edbauer D, Cheng D, Batterton MN, Wang CF, Duong DM, Yaffe MB, Peng J, Sheng M (2009) Identification and characterization of neuronal mitogen-activated protein kinase substrates using a specific phosphomotif antibody. Mol Cell Proteomics 8:681-695. CrossRef

Enz R (2007) The trick of the tail: protein-protein interactions of metabotropic glutamate receptors. Bioessays 29:60-73. CrossRef Medline

Enz R (2012) Metabotropic glutamate receptors and interacting proteins: evolving drug targets. Curr Drug Targets 13:145-156. Medline

Fagni L (2012) Diversity of metabotropic glutamate receptorinteracting proteins and pathophysiological functions. Adv Exp Med Biol 970:63-79. CrossRef Medline

Felder CC (1995) Muscarinic acetylcholine receptors: signal transduction through multiple effectors. FASEB J 9:619-625. Medline

Fotuhi M, Sharp AH, Glatt CE, Hwang PM, von Krosigk M, Snyder SH, Dawson TM (1993) Differential localization of phosphoinositide-linked metabotropic glutamate receptor (mGluR1) and the inositol 1,4,5trisphosphate receptor in rat brain. J Neurosci 13:2001-2012.

Francesconi A, Duvoisin RM (2000) Opposing effects of protein kinase $\mathrm{C}$ and protein kinase $\mathrm{A}$ on metabotropic glutamate receptor signaling: selective desensitization of the inositol trisphosphate/
$\mathrm{Ca}^{2+}$ pathway by phosphorylation of the receptor-G proteincoupling domain. Proc Natl Acad Sci U S A 97:6185-6190. CrossRef

Guo ML, Fibuch EE, Liu XY, Choe ES, Buch S, Mao LM, Wang JQ (2010) CaMKIlalpha interacts with M4 muscarinic receptors to control receptor and psychomotor function. EMBO J 29:20702081. CrossRef Medline

Hanke JH, Gardner JP, Dow RL, Changelian PS, Brissette WH, Weringer EJ, Pollok BA, Connelly PA (1996) Discovery of a novel, potent, and Src family-selective tyrosine kinase inhibitor. Study of Lck- and FynT-dependent T cell activation. J Biol Chem 271:695701. Medline

Hauck CR, Hunter T, Schlaepfer DD (2001) The v-Src SH3 domain facilitates a cell adhesion-independent association with focal adhesion kinase. J Biol Chem 276:17653-17662. CrossRef Medline

Hayashi T, Huganir RL (2004) Tyrosine phosphorylation and regulation of the AMPA receptor by Src family tyrosine kinases. J Neurosci 24:6152-6160. CrossRef Medline

Jin DZ, Guo ML, Xue B, Fibuch EE, Choe ES, Mao LM, Wang JQ (2013) Phosphorylation and feedback regulation of metabotropic glutamate receptor 1 by calcium/calmodulin-dependent protein kinase II. J Neurosci 33:3402-3412. CrossRef

Kato AS, Knierman MD, Siuda ER, Isaac JT, Nisenbaum ES, Bredt DS (2012) Glutamate receptor $\delta 2$ associates with metabotropic glutamate receptor 1 (mGluR1), protein kinase $\mathrm{C} \gamma$, and canonical transient receptor potential 3 and regulates mGluR1-mediated synaptic transmission in cerebellar Purkinje neurons. J Neurosci 32:15296-15308. CrossRef Medline

Kim CH, Lee J, Lee JY, Roche KW (2008) Metabotropic glutamate receptors: phosphorylation and receptor signaling. J Neurosci Res 86:1-10. CrossRef Medline

Knackstedt LA, Trantham-Davidson HL, Schwendt M (2013) The role of ventral and dorsal striatum mGluR5 in relapse to cocaineseeking and extinction learning. Addict Biol 19:87-101. CrossRef Knox R, Jiang X (2015) Fyn in neurodevelopment and ischemic brain injury. Dev Neurosci 37:311-320. CrossRef Medline

Köhr G, Seeburg PH (1996) Subtype-specific regulation of recombinant NMDA receptor-channels by protein tyrosine kinases of the src family. J Physiol 492:445-452. CrossRef

Kuwajima M, Hall RA, Aiba A, Smith Y (2004) Subcellular and subsynaptic localization of group I metabotropic glutamate receptors in the monkey subthalamic nucleus. J Comp Neurol 474:589-602. CrossRef

Liu XY, Mao LM, Zhang GC, Papasian CJ, Fibuch EE, Lan HX, Zhou HF, Xu M, Wang JQ (2009) Activity-dependent modulation of limbic dopamine D3 receptors by CaMKII. Neuron 61:425-438. CrossRef Medline

Lujan R, Nusser Z, Roberts JD, Shigemoto R, Somogyi P (1996) Perisynaptic location of metabotropic glutamate receptors mGluR1 and mGluR5 on dendrites and dendritic spines in the rat hippocampus. Eur J Neurosci 8:1488-1500. Medline

Manzoni OJ, Finiels-Marlier F, Sassetti I, Blockaert J, le Peuch C, Sladeczek FA (1990) The glutamate receptor of the Qp-type activates protein kinase $C$ and is regulated by protein kinase $C$. Neurosci Lett 109:146-151. Medline

Mao LM, Wang JQ (2016) Tyrosine phosphorylation of glutamate receptors by non-receptor tyrosine kinases: roles in depressionlike behavior. Neurotransmitter 3:e1118

Mao LM, Liu XY, Zhang GC, Chu XP, Fibuch EE, Wang LS, Liu Z, Wang JQ (2008) Phosphorylation of group I metabotropic glutamate receptors (mGluR1/5) in vitro and in vivo. Neuropharmacology 55:403-408. CrossRef Medline

Mao LM, Guo ML, Jin DZ, Fibuch EE, Choe ES, Wang JQ (2011) Posttranslational modification biology of glutamate receptors and drug addiction. Front Neuroanat 5:19. CrossRef

Martin LJ, Blackstone CD, Huganir RL, Price DL (1992) Cellular localization of a metabotropic glutamate receptor in rat brain. Neuron 9:259-270. Medline 
Medler KF, Bruch RC (1999) Protein kinase Cbeta and delta selectively phosphorylate odorant and metabotropic glutamate receptors. Chem Senses 24:295-299. Medline

Menegon A, Burgaya F, Baudot P, Dunlap DD, Girault JA, Valtorta F (1999) $\mathrm{FAK}^{+}$and PYK2/CAK $\beta$, two related tyrosine kinases highly expressed in the central nervous system: similarities and differences in the expression pattern. Eur J Neurosci 11:3777-3788. CrossRef

Nada S, Shima T, Yanai H, Husi H, Grant SG, Okada M, Akiyama T (2003) Identification of PSD-93 as a substrate of the Src family tyrosine kinase Fyn. J Biol Chem 278:47610-47621. CrossRef Medline

Neet K, Hunter T (1996) Vertebrate non-receptor protein-tyrosine kinase families. Genes Cell 1:147-169. Medline

Nicoletti F, Bockaert J, Collingridge GL, Conn PJ, Ferraguti F, Schoepp DD, Wroblewski JT, Pin JP (2011) Metabotropic glutamate receptors: from the workbench to the bedside. Neuropharmacology 60:1017-1041. CrossRef Medline

Niswender CM, Conn PJ (2010) Metabotropic glutamate receptors: physiology, pharmacology, and disease. Annu Rev Pharmacol Toxicol 50:295-322. CrossRef Medline

Ohnishi H, Murata $\mathrm{Y}$, Okazawa H, Matozaki T (2011) Src family kinases: modulators of neurotransmitter receptor function and behavior. Trends Neurosci 34:629-637. CrossRef

Okada M (2012) Regulation of the Src family kinase by Csk. Int J Biol Sci 8:1385-1397. CrossRef Medline

Orlando LR, Ayala R, Kett LR, Curley AA, Duffner J, Bragg DC, Tsai LH, Dunah AW, Young AB (2009) Phosphorylation of the homerbinding domain of group I metabotropic glutamate receptors by cyclin-dependent kinase 5. J Neurochem 110:557-569. CrossRef

Pabba M, Wong AYC, Ahlskog N, Hristova E, Biscaro D, Nassrallah W, Ngsee JK, Snyder M, Beique JC, Bergeron R (2014) NMDA receptors are upregulated and trafficked to the plasma membrane after sigma-1 receptor activation in the rat hippocampus. J Neurosci 34:11325-11338. CrossRef Medline

Panetti TS (2002) Tyrosine phosphorylation of paxillin, FAK, and p130CAS: effects on cell spreading and migration. Front Biosci 7:d143-d150. Medline

Ren R, Mayer BJ, Cicchetti P, Baltimore D (1993) Identification of a ten-amino acid proline-rich SH3 binding site. Science 259:11571161. Medline

Rinaldo L, Hansel C (2013) Muscarinic acetylcholine receptor activation blocks long-term potentiation at cerebellar parallel fiberPurkinje cells synapses via cannabinoid signaling. Proc Natl Acad Sci U S A 110:11181-11186. CrossRef Medline

Roskoski R Jr (2005) Src kinase regulation by phosphorylation and dephosphorylation. Biochem Biophys Res Commun 331:1-14. CrossRef Medline
Saito YD, Jensen AR, Salgia R, Posadas EM (2010) Fyn: a novel molecular target in cancer. Cancer 116:1629-1637. CrossRef Medline

Schenone S, Brullo C, Musumeci F, Biava M, Falchi F, Botta M (2011) Fyn kinase in brain diseases and cancer: the search for inhibitors. Curr Med Chem 18:2921-2942. Medline

Shigemoto R, Nomura S, Ohishi H, Sugihara H, Nakanishi S, Mizuno N (1993) Immunohistochemical localization of a metabotropic glutamate receptor, mGluR5, in the rat brain. Neurosci Lett 163:5357. Medline

Suzuki T, Okumura-Noji K (1995) NMDA receptor subunits epsilon 1 (NR2A) and epsilon 2 (NR2B) are substrates for Fyn in the postsynaptic density fraction isolated from the rat brain. Biochem Biophys Res Commun 216:582-588. Medline

Tabatadze N, Huang G, May RM, Jain A, Woolley CS (2015) Sex differences in molecular signaling at inhibitory synapses in the hippocampus. J Neurosci 35:11252-11265.

Tayebati SK, Vitali D, Scordella S, Amenta F (2001) Muscarinic cholinergic receptors subtypes in rat cerebellar cortex: light microscope autoradiography of age-related changes. Brain Res 889: 256-259. Medline

Thomsen C, Mulvihill ER, Haldeman B, Pickering DS, Hampson DR, Suzdak PD (1993) A pharmacological characterization of the mGluR $1 \alpha$ subtype of the metabotropic glutamate receptor expressed in a cloned baby hamster kidney cell line. Brain Res 619:22-28. CrossRef

Traynelis SF, Wollmuth LP, McBain CJ, Menniti ES, Vance KM, Ogden KK, Hansen KB, Yuan H, Myers SJ, Dingledine R (2010) Glutamate receptor ion channels: structure, regulation, and function. Pharmacol Rev 62:405-496. CrossRef Medline

Trepanier CH, Jackson MF, MacDonald JF (2012) Regulation of NMDA receptors by the tyrosine kinase Fyn. FEBS J 279:12-19. CrossRef Medline

Twamley GM, Kypta RM, Hall B, Courtneidge SA (1992) Association of Fyn with the activated platelet-derived growth factor receptor: requirements for binding and phosphorylation. Oncogene 7:18931901. Medline

Twamley-Stein GM, Pepperkok R, Ansorge W, Courtneidge SA (1993) The Src family tyrosine kinases are required for plateletderived growth factor-mediated signal transduction in NIH 3T3 cells. Proc Natl Acad Sci U S A 90:7696-7700. Medline

Umemori H, Wanaka A, Kato H, Takeuchi M, Tohyama M, Yamamoto $\mathrm{T}$ (1992) Specific expression of Fyn and Lyn, lymphocyte antigen receptor-associated tyrosine, in the central nervous system. Mol Brain Res 16:303-310. Medline

Wess J (1996) Molecular biology of muscarinic acetylcholine receptors. Crit Rev Neurobiol 10:69-99. Medline

Whitham EM, Challiss RA, Nahorski SR (1991) M3 muscarinic cholinoceptors are linked to phosphoinositide metabolism in rat cerebellar granule cells. Eur J Pharmacol 206:181-189. Medline 